\title{
Early Holocene to Present Paleoenvironmental Shifts and Short Climate Events Inferred from Tropical Wetland and Lake sediments, Kukkal Lake, Southern India: Geochemistry and Palynology
}

\author{
Vijayaraj R \\ Department of Geology \\ Anna University, Chennai 600025. \\ Email:vijayuniverse@gmail.com
}

Hema Achyuthan

Department of Geology

Anna University Chennai 600025

hachyuthan@yahoo.com

Christopher Eastoe

Department of Geosciences

University of Arizona, Tucson, AZ 85721, USA

eastoe@email.arizona.edu

\section{Anjum Farooqui}

Birbal Sahni Institute of Paleobotany

Lucknow 226007

Afarooqui_2000@yahoo.com 
Early Holocene to Present Paleoenvironmental Shifts and Short Climate Events Inferred from Tropical Wetland and Lake sediments, Kukkal Lake, Southern India: Geochemistry and Palynology

Vijayaraj R ${ }^{1}$, Hema Achyuthan ${ }^{1}$, Christopher Eastoe ${ }^{2}$ and Anjum Farooqui $^{3}$

1. Department of Geology, Anna University, Chennai 600025

2. Department of Geosciences, University of Arizona, Tucson, AZ 85721

3. Birbal Sahni Institute of Paleobotany, Lucknow 226007

\section{Abstract}

The Kukkal basin, Tamil Nadu, India, receives most of its rain from the southwest monsoon. A sediment core from Kukkal Lake, preserves a continuous sediment record from the Early Holocene to present (9000 yr BP to present). The present lake is artificial, situated at an elevation of $\sim 1887$ $\mathrm{m}$ a.s.l.,, in a small basin that appears to have alternated between a and wetland depositional environment. Climate proxies, including sediment texture, TOC, Total Nitrogen $(\mathrm{TN}), \mathrm{C} / \mathrm{N}$, pollen and geochemical composition indicate a steady progression to wetter conditions, with two stepwise changes at about 8000, and between 3200 and 1800 yr BP. The change at 8000 yr BP appears to correspond to a brief (100-150 yr) dry spell recorded elsewhere in India. The change at 3200-1800 yr BP consisted in a rapid intensification of the southwest monsoon, and may correlate with the initiation of the Roman Warm Period. There is no clear evidence of changes at the times of the Medieval Warm Period and the Little Ice Age. A warm period (1150-850 yr BP) and Little Ice Age (LIA) (550-150 yr BP) of wetter 
conditions events are observed in the Kukkal lake. The $\mathrm{C} / \mathrm{N}$ ratio of the sediments ranges from 14.02 to 8.31 indicating that the organic matter originated from a mixture of lacustrine algae and vascular plants. Chemical weathering indices (CIA, CIW and PIA) are consistent with extreme silicate weathering. Pollen data show a development from savanna vegetation prior to about 8000 yr BP, followed by grassland with palms, the appearance of ferns just prior to 3200 yr BP, and the establishment of forest between 3200 and about 1800 yr BP.

Key words: Tropical lake, tropical wetland, Holocene, monsoonal intensity, pollen, radiocarbon dating, climate change 


\section{INTRODUCTION}

During the last two decades scientific interest in the reconstruction of the Asian monsoon variations particularly the South West Monsoon (SWM) since the Late Quaternary to Holocene period has increased significantly. In particular, in the Indian subcontinent many types of natural archives such as lake and marine sediment cores, palynology, tree rings and corals (Mayewski et al., 2004) have been used to restructure late Quaternary-Holocene paleoclimatic shifts. Such records include fluvial archives of the Gujarat region (Chamyal et al., 2002), deep marine sediment cores studied from the Arabian Sea, and the Bay of Bengal (Gupta et al., 2003, 2005; Chauhan et al., 2010; Nagasundaram 2014; Achyuthan et al., 2015), aeolian sediments from the Thar desert (Achyuthan et al., 2007a, b), lacustrine sediments from Kerala (Farooqui and Sekhar 2011; Farooqui et al., 2010; Kumaran et al., 2008; Veena et al., 2014), peat deposits from the foreland basin of the Himalyas (Sharma et al., 2006; Rawat et al., 2015), glacial moraines and proglacial deposits of the Ladakh region (Sant et al., 2011), speleothems (Narayana et al., 2011) and tree rings (Esper et al., 2002 a, b, 2003; Yadav and Singh 2002; Shah and Bhattacharya, 2009).

The Indian subcontinent is one of the largest monsoon-dominated regions of the world and the climate is controlled primarily by the SWM. Lakes and wetlands in this region function as repositories of sediment deposited in a closed system, and may act as major sinks for organic carbon. Therefore, sediment cores from such sites in the area affected by the SWM can provide a continuous, highresolution of paleoenvironmental record of the evolution of the SWM (Verschuren, 2003; Verschuren et al., 2000).

It is important to reconstruct past climate and to study paleoclimate records with high resolution because the past performance of the monsoon may provide vital input for projecting future climate change. Furthermore, an understanding of climate change in the Indian subcontinent from the early Holocene to the present potentially has profound implications for an understanding of human 
development, because rain-fed agriculture and river valley civilisation were established during this time interval (Possehl 1996; Allchin 1997; Gupta 2004, Ponjtoon et al., 2014).

In the Asian region, paleoclimate records based on lake sediments indicate that both southwest summer and northeast winter rains were stronger in the early Holocene period $(10,000-7000$ yr BP) than today, resulting in a wetter and cooler climate over the Asian continent. But the Holocene Megathermal was a much warmer phase in areas that received East Asian monsoon (An et al., 2000; Wang et al., 2005; Sun and Li, 2011). Warming started around 8000 yr BP and the Holocene Megathermal Maximum (HMM), occurred between 7200 and 6000 yr BP. After 3000 yr BP, climate in China area returned to a cold and dry state (Sun and Li, 2011). These conclusions are based on a wide variety of proxies, including pollen and diatoms (Prell and Kutzbach, 1987; Van Campo et al., 1996), oxygen isotopes from marine sediments (Sirocko et al., 1993, 1996), and Arabian Sea upwelling intensities (Prell and Van Campo, 1986; Overpeck et al., 1996). Staubwasser et al., (2002, 2003) provided some insight in the climate variability in the SWM region since the mid Holocene.

A history of flow volume of the Indus River over the past 5000 yr has been reconstructed by von Rad et al. (1999 a, b). The Indus has a large catchment in a region that is now partly semi-arid. Being fed by melting Himalayan ice as well as precipitation in the semi-arid hinterland, its discharge is governed by a complex interplay of phenomena. Information obtained to date shows a stronger SWM since about 1500 yr BP.

Temperature indicators are less clear, except around the Medieval Warm Period (MWP) ( ～) and the Little Ice Age (LIA) (Crowley and Lowery 2000). Chauhan and Vogelsang (2006) reported that the LIA had a large temporal and spatial variability due to the variations in the intensity of SWM and had its impact across the globe. A period of warming in Oman coeval with that in China, was observed from the index fossil Globigerinoides bulloides, which indicates wind- 
induced upwelling of ocean water, during the interval $1200 \mathrm{yr}$ BP to $600 \mathrm{yr}$ BP (Gupta et al., 2003). However, in the northern hemisphere, the LIA was a mild cooling event (Crowley and Lowery 2000; Crowley, 2000; Anderson et al., 2002; Sighvi and Kale, 2008). Summarizing these studies, it is evident that a significant variation of the SWM, encompassing several cycles of fluctuations, occurred during the Holocene.

To date, the marine record from the Arabian Sea has proved to be the most consistent and continuous record of the SWM fluctuations (Sirocko et al., 1993, 1996, 2000; Kudrass et al., 2001; Lückge et al., 2001; Thamban et al., 2002; Tiwari et al., 2005, 2006), whereas limited studies have been carried out in the Bay of Bengal (Duplessy, 1982; Chauhan et al., 2004; Chauhan and Vogelsang, 2006; Achyuthan et al., 2015). However, lakes of peninsular India preserve a great wealth of paleoenvironmental and paleoclimate data spanning the last $6000 \mathrm{yr}$ as described by Limaye et al., (2010) and Veena et al., (2014). The lake and wetland archives of Tamil Nadu have received so far little attention. Kukkal Lake, in the Palani Hills, Dindigul District, Tamil Nadu State, lies in a basin affected by both the SWM and NEM rains. Hence, the main objectives of the present study are to reconstruct the Holocene paleomonsoon and paleoenvironmental shifts using the Kukkal lake sediments.

\section{STUDY AREA}

Kukkal Lake (Figure 1) (lat and long ) is a small, irregular, fresh water body covering an area of 18 ha, and situated at an altitude of $1887 \mathrm{~m}$ above sea level. The present lake is impounded by a low dam at the northern end, and floods an area that appears to have been a wetland similar to one about $300 \mathrm{~m}$ south of the lake. Both features may have been lakes at times in the past. Presently, the lake has an catchment area of 2 to $3 \mathrm{~km}^{2}$, that is forested and relatively undisturbed by human activities; some abandoned paddies on the east side of the lake are the only evidence of agriculture in the catchment. Sediment in the basin beneath the lake is therefore suitable for carrying out paleoenvironment research. Bedrock underlying the catchment is Precambrian charnockite associated with hornblende-biotite gneiss, granite and quartzite, and is covered by a thin veneer of red vertisol and lateritic soil 
(Bagyaraj and Gurugnanam, 2011). The geology and geomorphic observations in and around the lakes reveal that the Kukkal Lake basin is structurally controlled by faults and lineaments, as are the main tributary watercourses within the basin. The catchment receives rainfall from both the SWM and NEM, the NEM being dominant (Meher-Homji and Gupta 1999). The mean annual rainfall for Kodaikanal over a four-year period (2001-2004) was 1690 mm (Bagyaraj and Gurugnanam, 2011). The dry season is from December through March, and there is also a short dry period in July. The climate is salubrious for most of the year with summer temperatures reaching $19.8^{\circ} \mathrm{C}(\max )$ and $11.3^{\circ} \mathrm{C}(\mathrm{min})$ and winter temperatures between $17.3^{\circ} \mathrm{C}(\max )$ and $8.3^{\circ} \mathrm{C}(\min )$. Meher-Homji and Gupta (1999) state that Kodaikanal experiences a bixeric climate regime receiving high rainfall from ocotber to December (ie. NEM). The lake is surrounded by the 'Shola' forests (the word 'Shola' derived from the tamil language word 'cÕlai' meaning grove or thick vegetation cover (Meher-Homji 1967). The Sholas are patches of stunted tropical montane forest found in the valleys in the midst of rolling grassland in the higher montane regions of the Nilgiri Hills, South India. The soil texture varies from clay to silty clay; soils are acidic in nature and contain a high percentage of iron oxide and alumina. In the 'Shola' forests, accumulation of humus in the top layers of the soil renders it a black color (Meher-Homji, 1967; Bera and Farooqui, 2000).The dominant trees in the shola forest are represented by Michelia niligarica, Bischofia javanica (bishop wood), Calophyllum tomentosa, Cedrela toona (Indian mahogany), Eugenia (myrtle) spp., Ficus glomerata and Mallotus spp. and small trees such as Pygeum gardneri, Schefflera racemosa, Linociera ramiflora, Syzygium spp., Rhododendron nilgiricum, Mahonia nepalensis, Elaeocarpus recurvatus, Ilex denticulata, Michelia nilagirica, Actinodaphne bourdellonii, and Litsea wightiana. These forests are interspersed with grasslands, characterized by frost and fireresistant grass species like the Chrysopogon zeylanicus, Cymbopogon flexuosus, Arundinella ciliata, Arundinella mesophylla, Arundinella tuberculata, Themeda tremula, and Sehima nervosum.

\section{MATERIALS AND METHODS}




\section{Field methods}

The field map was prepared using Survey of India toposheets, a Google Earth map, and Satellite imagery data products IRS LISS III for delineating faults, lineaments and channels draining into the lake. Faults and the rock types exposed around the lake surroundings were also noted. An acid-washed $6.4 \mathrm{~cm}$ diameter and of nearly $94 \mathrm{~cm}$ in length PVC pipe sediment core was raised from the lake floor. The sediment core sampled location was marked using a Garmin III Global Positioning System (GPS) (Fig.1), subsampled at 2cm interval, stored in clean zip locked polythene bag, marked and stored for further analyses.

\section{Chemical and Physical analyses}

For the sediment texture analyses, about of $5 \mathrm{~g}$ of the dried sediment was washed following Carver (1971) through a 230 American standard testing machine (ASTM) sieve mesh opening of $0.063 \mathrm{~mm}$ until the water passing through was clear (Tables 1, 2). This separted the sand from the silt and clay content. The sediments collected in the 230 sieve mesh was calculated as sand content. Silt and clay percentage were determined using the measuring jar and settling velocity experiment following Carver (1971). Procedures of Loring and Rantala (1992) and Piper (1947) were adopted for the determination of calcium carbonate content. The organic matter $(\mathrm{OM})$ in the sediment sample was determined following the procedure of Gaudette et al., (1974). The Total Organic Carbon (TOC) and Total Nitrogen (TN) were determined using about $1 \mathrm{~g}$ of sediment sample, decarbonated with a $1 \mathrm{M}$ solution of hydrochloric acid, washed three times with deionized water, freeze-dried and then analyzed in a Thermo Scientific FLASH 2000 CHNS-O Organic Elemental Analyzer (OEA) at the Department of Geology, Anna University, Chennai (Table 3). Major oxide and trace element analyses were carried out at the Central Instrumentation Facility (CIF) at Pondicherry University, Pondicherry using a WDXRF Spectrometer with samples in powder form. The samples were analysed for $\mathrm{SiO}_{2}, \mathrm{Al}_{2} \mathrm{O}_{3}, \mathrm{Na}_{2} \mathrm{O}, \mathrm{CaO}, \mathrm{Fe}_{2} \mathrm{O}_{3}, \mathrm{~K}_{2} \mathrm{O}, \mathrm{TiO}_{2}, \mathrm{P}_{2} \mathrm{O}_{5}, \mathrm{MnO}, \mathrm{MgO}$ and $\mathrm{Sr}, \mathrm{Cr}, \mathrm{Cu}, \mathrm{Ni}$, Co, Pb, Zn, V, Ba, and Zr (Tables 4 and 5, Figure 4). Results were normalized to $\mathrm{Al}$ (Figure 4). 


\section{Calculation of chemical indices}

The degree of rock alteration and weathering can be estimated quantitatively using several geochemical indices (e.g., Duzgoren-Aydin et al., 2002; Maslov et al., 2003; Price and Velbel, 2003; Yudovich and Ketris, 2011). However, for the charnockite and gneisses exposed around the study area weathering indices till date have not been calculated. Most of these indices are expressed in terms of molecular or weight percentages of various oxides or groups of oxides. During chemical weathering, more labile minerals, such as feldspar and plagioclase, are depleted in $\mathrm{Ca}^{2+}, \mathrm{K}+$ and $\mathrm{Na}+$ and transformed into minerals that are more stable under surface conditions. As the intensity of weathering increases, rocks and sediments become enriched in $\mathrm{Al}, \mathrm{Ti}, \mathrm{Fe}$, and Mn (Minyuk et al., 2014).

Chemical Index of Alteration (CIA): The CIA was defined as follows by Nesbitt and Young (1982) using molecular proportions:

$$
\mathrm{CIA}=\left[\mathrm{Al}_{2} \mathrm{O}_{3} /\left(\mathrm{Al}_{2} \mathrm{O}_{3}+\mathrm{CaO}+\mathrm{NaO}+\mathrm{K}_{2} \mathrm{O}\right)\right] \times 100
$$

with $\mathrm{CaO}$ being the amount of $\mathrm{CaO}$ incorporated in the silicate fraction of the rock. The CIA measures the proportion of $\mathrm{Al}_{2} \mathrm{O}_{3}$ versus more labile oxides, and reflects the relative amount of feldspars and clay minerals in a sample. A CIA value of 50 corresponds to unaltered albite, anorthite, and potassic feldspar. Typical values of the CIA are 30 to 40 for basalt, 45 to 55 for granites and granodiorites, 75 to 85 for illite, 75 for muscovite, and close to 100 for kaolinite and chlorite (Nesbitt and Young, 1982).

Chemical Index of Weathering (CIW) This index was proposed by Harnois (1988) and is calculated using the equation:

$$
\mathrm{CIW}=\left[\mathrm{Al}_{2} \mathrm{O}_{3} /\left(\mathrm{Al}_{2} \mathrm{O}_{3}+\mathrm{CaO}+\mathrm{Na}_{2} \mathrm{O}\right)\right] \times 100
$$

with $\mathrm{Al}_{2} \mathrm{O}_{3}$ treated as an immobile component and $\mathrm{CaO}$ and $\mathrm{Na}_{2} \mathrm{O}$ as mobile elements. $\mathrm{K}$, in contrast, is not included in this index, because it may be leached and/or accumulated in the residual weathering products. Fedo et al., (1995) 
suggested that $\mathrm{Al}$ in this index be used without any correction for its occurrence in K-feldspar, and therefore, generally K-feldspar- rich rocks yield very high CIW values. Potassic granite, for example, has a CIW value of 80 and fresh K-feldspar has an index of 100, values that are similar to those of the residual products of chemical weathering e.g., 80 for smectite, and 100 for kaolinite, illite and gibbsite.

Plagioclase Index of Alteration (PIA): This index (Fedo et al., (1995) estimates the weathering intensity of plagioclase feldspar and is calculated as follows :

$$
\mathrm{PIA}=\left[\left(\mathrm{Al}_{2} \mathrm{O}_{3}-\mathrm{K}_{2} \mathrm{O}\right) /\left(\mathrm{Al}_{2} \mathrm{O}_{3}+\mathrm{CaO}+\mathrm{Na}_{2} \mathrm{O}+\mathrm{K}_{2} \mathrm{O}\right)\right] \times 100
$$

Chemical Weathering Intensity (CWI): Oxides such as $\mathrm{CaO}, \mathrm{MgO}$, and $\mathrm{Na}_{2} \mathrm{O}$ are considered more soluble and mobile, while $\mathrm{Al}_{2} \mathrm{O}_{3}, \mathrm{SiO}_{2}$, and $\mathrm{TiO}_{2}$ are considered to be more insoluble and resistant (Mackereth, 1966a, b, Engstrom and Wright, 1984). Sun et al., (2010) proposed the CWI as an alternative to the CIA in order to understand the intensity of weathering and apparently wet or dry conditions. The CWI was calculated as follows, using molecular proportions:

$$
\mathrm{CWI}=\left[\left(\mathrm{CaO}+\mathrm{MgO}+\mathrm{Na}_{2} \mathrm{O}\right) / \mathrm{Al}_{2} \mathrm{O}_{3}\right] \times 100
$$

\section{Palynology}

Forty eight sediment samples (taken at $2 \mathrm{~cm}$ intervals) were analysed. Ten grams of each sample was treated with warm $10 \%$ potassium hydroxide and later sieved through 150 ASTM mesh $(105 \mu \mathrm{m})$. The sieved fraction was allowed to settle overnight and the supernatant was drained. The residue was treated with $40 \%$ hydrofluoric acid. The sample was then acetolysed, following Faegri and Iversen (1989). The 650 mesh $(10 \mu \mathrm{m})$ fraction was collected and mounted on a glass slide in glycerine jelly for palynological study under a light microscope (Olympus BX$52)$.

\section{Radiocarbon dating}


Four organic carbon rich samples from the core were subjected to acidbase-acid pre-treatment, and dated by liquid scintillation counting on benzene at the Department of Geosciences, University of Arizona, Tucson, USA. The radiocarbon ages were then calibrated using Calib 6.0 (Stuiver et al., 2010) following Stuiver and Reimer (1993) method.

\section{RESULTS}

\section{Lithology}

Based on the colour and texture, three litho units were recognized in the core. Litho unit I (100-47 cm) is represented by black coloured (10 Y 2/1) Munsell color scale codes, fine sandy silt, clayey silt and silty sand, peaty layers, overlain by lithological unit II $(47-28 \mathrm{~cm})$ which is brownish black (10 Y 2/3) in colour, moderately sorted, sandy silt and silty sand, peat laminae, with sub angular to angular grains. Lithological unit III $(28-0 \mathrm{~cm})$ is brownish black $(10 \mathrm{Y} \mathrm{3/1})$ in colour, and consists of sandy silt and silty sand laminae, peat with well rounded sand grains. It contains coarse organic carbon pellets and abundant roots and root pores (Table 1, Figures 2 and 3).

\section{Chronology}

Radiocarbon dates (Figure 2), (Table 2 ) range from 9105 yr BP (99 cm depth, 9255 BC) to near modern (99.7 pMC at 17 cm depth, or AD 1650-1955). The plot of depth versus age indicates that the sedimentation rate from the early Holocene to recent was low $(0.11 \mathrm{~mm} / \mathrm{yr})$ throughout the time interval from 14 to $100 \mathrm{~cm}$, with small variations as follows: $0.19 \mathrm{~mm} / \mathrm{yr}$ from $9105 \mathrm{yr}$ BP to $7640 \mathrm{yr}$ BP; $0.06 \mathrm{~mm} / \mathrm{yr}$ from $7640 \mathrm{yr}$ BP to $3215 \mathrm{yr}$ BP (71-43 cm depth) and $0.08 \mathrm{~mm} / \mathrm{yr}$ from $3215 \mathrm{yr}$ BP to about $150 \mathrm{yr}$ BP. Above $14 \mathrm{~cm}$, the deposition rate is higher, with a minimum value, calculated by attributing an age of 300 yyr BP at $14 \mathrm{~cm}$, of $0.4 \mathrm{~mm} / \mathrm{a}$.

\section{Stable Carbon Isotopes}


Values of $\delta^{13} \mathrm{C}$ of organic carbon in the sediment show a general upward decrease from near -16\% at 98-100 cm (9105 yr BP) to near -23\%o at present (Table 2). The transition can best be explained as the result of a decreasing proportion of organic matter derived from $\mathrm{C} 4$ plants over time. Both $\mathrm{C}_{3}$ and $\mathrm{C}_{4}$ sedges grow at present in a peat bog in a similar tropical montane environment in the Nilgiri Hills, Tamil Nadu State, India (Rajagopalan et al., 1999).

\section{Sediment texture}

Textural analysis of clastic fraction of the Kukkal sediment core is shown in Figure 3. The sand percentage ranges from 12.5\% (depth $70 \mathrm{~cm}$ ) to $92 \%$ (depth $50 \mathrm{~cm}$ ). The silt percentage ranges from 8\% (depth $50 \mathrm{~cm}$ ) to 75\% (depth 70 $\mathrm{cm}$ ), while the clay ranges from $0.5 \%$ (depth $50 \mathrm{~cm}$ ) to $17 \%$ (depth $85 \mathrm{~cm}$ ). Three main zones are apparent: below about $65 \mathrm{~cm}$, with silt $>$ sand and clay $>10 \%$; fromabout 60 to $40 \mathrm{~cm}$, sand predominant, clay <5\%; above $40 \mathrm{~cm}$, sand and silt about equal, and clay $<5 \%$. Most of the sediment core contains $>25 \%$ organic matter consistent with a lacustrine or wetland environment. Recurring peaty sediment suggests that a wetland environment may have prevailed over much or all of the interval represented by the sediment core, prior to construction of the dam.

\section{Sediment chemistry}

TOC content increases steadily up the section from about $3.5 \%$ at $85-100$ cm to $15.8 \%$ at $1 \mathrm{~cm}$ (Figure 3, Table 3). Similarly, TN content increases gradually from $0.4 \%$ (depth $85-100 \mathrm{~cm}$ ) to $1.0-1.3 \% \%$ (depth $0-30 \mathrm{~cm}$ ) and the $\mathrm{C} / \mathrm{N}$ ratio increases gradually from about $8 \%$ (depth $85-100 \mathrm{~cm}$ ) to $14 \%$ (depth $1 \mathrm{~cm}$ ). A C/N ratio 13-14 suggests a sub-equal mixture of algal and vascular plant contributions (Meyers and Lallier-Vergès 1999). Intervals of low $\mathrm{C} / \mathrm{N}$ ratio $(<9)$ occur at 12-14, 22-24, 30-34, 40-44 and 76-100 cm core depth (Figure 3). The sample at 2-4 cm probably represents the present artificial lacustrine environment, and has a $\mathrm{C} / \mathrm{N}$ ratio of 14, indicating that vascular and algal plant material is deposited in shallow standing water in this enviromnment. At the depth 40 to $35 \mathrm{~cm}$ a concurrent 
decrease in OM, TOC, and TN is immediately follows a sharp decrease in sand deposition.

The vertical profile of the major oxides versus depth (Table 4, Figure 4 and 5) shows that the lake sediments have $\mathrm{SiO}_{2}$ varying from 31 (depth $70 \mathrm{~cm}$ ) to $47 \%$ (depth $35 \mathrm{~cm}$ ), with $\mathrm{Al}_{2} \mathrm{O}_{3}$ from $13 \%$ (depth $20 \mathrm{~cm}$ ) to 22\% (depth $80 \mathrm{~cm}$ ), and $\mathrm{Fe}_{2} \mathrm{O}_{3}$ from 5 (depth $50 \mathrm{~cm}$ ) to $9 \%$ (depth $75 \mathrm{~cm}$ ). $\mathrm{TiO}_{2}$ varies from $0.9 \%$ (depth 10 $\mathrm{cm}$ ) to $1.3 \%$ (depth $40 \mathrm{~cm}$ ). $\mathrm{K}_{2} \mathrm{O}, \mathrm{CaO}, \mathrm{MgO}, \mathrm{MnO}$ and $\mathrm{Na}_{2} \mathrm{O}$ are present in small $(<2 \%)$ amounts. The relative concentrations of the major oxides in the sediment core can be summarized as $\mathrm{SiO}_{2}>\mathrm{Al}_{2} \mathrm{O}_{3}>\mathrm{Fe}_{2} \mathrm{O}_{3}>\mathrm{TiO}_{2}>\mathrm{MgO}>\mathrm{CaO}>$ $\mathrm{K}_{2} \mathrm{O}>\mathrm{P}_{2} \mathrm{O}_{5}>\mathrm{MnO}>\mathrm{Na}_{2} \mathrm{O}$. Most of the oxide trends show two prominent features: decreases in $\mathrm{SiO}_{2}, \mathrm{Al}_{2} \mathrm{O}_{3}, \mathrm{Fe}_{2} \mathrm{O}_{3}$ nd $\mathrm{TiO}_{2}$ at 30-35 cm, accompanied by increases in $\mathrm{P}_{2} \mathrm{O}_{5}, \mathrm{MnO}$ and $\mathrm{CaO}$; and at 70-80 cm, decreases in $\mathrm{SiO}_{2}, \mathrm{Al}_{2} \mathrm{O}_{3}, \mathrm{P}_{2} \mathrm{O}_{5}$ and $\mathrm{K}_{2} \mathrm{O}$ (Figure 5). Discriminant plots of major oxides point towards intense weathering of exposed rocks around the catchment area (Figures 6, 7, 8a, b) accompanied by an increase in $\mathrm{Fe}_{2} \mathrm{O}_{3}$. There is an overall significant decrease of $\mathrm{Al}_{2} \mathrm{O}_{3}$ (about 10\%) since 9105 yr BP (Figure 4).

In the sediment sequence of the Kukkal lake core, the values of the CWI increase from 4-6 (characteristic of depths below $40 \mathrm{~cm}$ ) to 8-10 (characteristic of depths above $30 \mathrm{~cm}$ ) (Figure 9). Generally, higher values of CWI indicate stronger weathering and presumably wetter conditions and a strong monsoon (Sun et al., 2010). Concurrent decreases occur in the values of the CIA, PIA and CIW between 40 and $30 \mathrm{~cm}$ (Figure 9). The shifts in all four indices reflect an increase in $\mathrm{CaO}$ concurrent with a decrease in $\mathrm{Al}_{2} \mathrm{O}_{3}$ between 40 and $30 \mathrm{~cm}$.

\section{Palynology}

The pollen spectra are shown in Figure 10, and pollen types are illustrated in Fig. 11. The best preservation of pollen is in the upper layer $(0-27 \mathrm{~cm})$. Arboreal taxa appear above $27 \mathrm{~cm}$ and below $87 \mathrm{~cm}$ core depth, while grasses and palms are prominent between 27 and $87 \mathrm{~cm}$ and sedges are most prominent above $27 \mathrm{~cm}$. Monolete and trilete fern spores are abundant above $28 \mathrm{~cm}$. 
Pollen is poorly preserved between 27 and $87 \mathrm{~cm}$ core depth, but grass pollen is abundant. Grasses are also represented by phytoliths. On the basis of palynological analysis four phases couldbe recognised. Phases I to III in general correspond to a fluvial depositional environment (Figure 10, 11). However, phase-I (87-100 depth $\mathrm{cm}$ ) can be identified with low energy deposition and as a result, sparse deposition and preservation of arboreal pollen such as Elaeocarpus, Hopea and the non-arboreal taxa like the Euphorbiaceae, Lamiaceae, and Apiaceae. Asteraceae along with Cyperaceae and Poaceae pollen were recorded. Phases II (4187 depth $\mathrm{cm}$ ) and III (27-41 depth $\mathrm{cm}$ ) are represented by dominance of the Artemisia, Poaceae and Cyperaceae along with the pollen grains of Palmae. Overall, the pollen counts in Phases 1-3 are low and reach maximally 40 to 50 per $10 \mathrm{~g}$ of sediment (Figure 10,11). Dumbbell shaped grass phytoliths and other forms of phytoliths such as bulliform and spiny are quite common. Phase IV, shows assemblage of both arboreal and non-arboreal pollen assemblage in (Figure 10, 11).

\section{Discussion}

\section{Sedimentary environment}

The chronology of the core, and inferred measurements of sedimentation rate, indicates a sedimentary environment that has been continuous and close to stable in this small basin for the past 9000 yr. However, highproportion of sand deposited between 60to $45 \mathrm{~cm}$ internval indicate a faster accumulation rates. Peatlike deposits of organic matter are consistent with a wetland environment like those present elsewhere in montane valleys of the tropical Western Ghats. Variations in the $\mathrm{C} / \mathrm{N}$ ratio of organic matter may indicate changes in the abundance of algae in the basin flora, and, by implication, changes in the amount of standing water in the basin (Figure 3). The basin may have been lacustrine for relatively brief intervals corresponding to $12-14,22-24,30-34$, and $40-44 \mathrm{~cm}$, in addition to a longer interval corresponding to $76-100$, $\mathrm{cm}$ in the core (Figures 4, 5). The present-day lacustrine environment is due to damming. Superimposed on this sedimentary system are 
changes revealed by our climate proxy measurements - both unidirectional steady changes, and abrupt events.

\section{Unidirectional changes}

The chemistry of the OM in the core has evolved steadily over the past 9000 yr. TOC, TN and C/N all show an upward increase in the core (Figure 3). The values of $\delta^{13} \mathrm{C}$ also suggest an increase. A progression from mainly $\mathrm{C}_{4}$ to mainly $\mathrm{C}_{3}$ species in the basin is indicated, and this is in support with an increasingly wet climate. Increasing rainfall may also be responsible for the increasing amount of organic matter over time, preservation being more likely when the basin sediments remain wet for long periods. The $\mathrm{CaO} / \mathrm{MgO}$ ratio in the silicate fraction also increases towards the top of the core section, and $\mathrm{Al}_{2} \mathrm{O}_{3}$ decreases.

\section{Step-wise changes}

Several proxies show step-wise changes in the range 30-40 cm. Major oxide measurements change in such a way that all four chemical weathering indices calculated for this study shift to new values corresponding to more intense weathering over that depth interval. $\mathrm{Fe}_{2} \mathrm{O}_{3}, \mathrm{MnO}$ and $\mathrm{P}_{2} \mathrm{O}_{5}$ also show shifts. The changes in chemical indices are concurrent with increases in $\mathrm{Ca} / \mathrm{Al}$ and $\mathrm{Si} / \mathrm{Al}$ (Figure 5), but there is no change in the relative abundance of clay (Figure 3). Proportions of Asteraceae, Poaceae and palmae or Arecaceae decrease markedly in the record over this depth interval (Figures 10,11). These changes immediately follow a change in the character of clastic sedimentation from sand-dominant to sand and silt in approximately equal proportions. They are succeeded rapidly by a further change in the pollen record, namely enhanced preservation of arboreal Ferns increase in abundance earlier, at depths of 46 to $40 \mathrm{~cm}$ in the core. This change is at ca $3000 \mathrm{yr} \mathrm{BP}$ (at $40 \mathrm{~cm}$ ) to $1800 \mathrm{yr} \mathrm{BP}$ (at $30 \mathrm{~cm}$ ). A step-wise change similar to that reflected in enhanced preservation of pollen and the appearance of diatoms just above $30 \mathrm{~cm}$ in the Kukkal core and occurred at 1500 yr BP in Pookode Lake, Kerala, at an altitude of 770 ma.s.l (Veena et al., 2014). 
As noted before, the shifts in the chemical indices appear to relate to increased deposition of $\mathrm{CaO}$ as silicate minerals, and concurrent increase in $\mathrm{Si} / \mathrm{Al}$. A change in clay mineralogy, with deposition of Ca-smectite above $30 \mathrm{~cm}$, is a possible way of accounting for the change. The increase in CWI indicates a greater intensity of weathering, but deposition of sediment bearing this signature is likely to have lagged behind the climate stimulus responsible for the change. Together, most of the observations suggest a period of increasing rainfall. The changes may even have begun as early as $6000 \mathrm{yr} \mathrm{BP}$, when sand began to dominate the clastic sediment, and have led to more abundant fern vegetation by $3500 \mathrm{yr}$ BP, and forest vegetation largely replacing grasslands with palms by1700 yr BP. This change might account for the decrease in sand deposition at about $1700 \mathrm{yr} \mathrm{BP}$, if the change to forest vegetation led to less energetic runoff.

The increase in sand deposition near $6000 \mathrm{yr}$ BP could be a separate stepwise event, independent of the events beginning around 3500 yr BP. A further stepwise event is indicated at $90 \mathrm{~cm}$ in the core, (about $8700 \mathrm{yr} \mathrm{BP}$ ), prior to which some arboreal pollen and fern spores were preserved. Above this horizon, the relative abundances of sand, silt and clay change abruptly in the sediment core towards the top. Major oxide trends show inflections at about $80 \mathrm{~cm}$, possibly resulting from the same event, with a lag reflecting the time required for weathering chemistry to respond.

\section{Human effects}

The higher sediment deposition rate between 0 and $14 \mathrm{~cm}$ in the core corresponds to events of the last $350 \mathrm{yr}$ or less, and is the only evidence consistent with human-caused changes in the lake catchment. As noted above, abandoned paddy terraces are present along the east side of the catchment. Agriculture may have become established in this montane site since the early $17^{\text {th }}$ century. Cutting of trees in the forested part of the catchment may also have contributed to the increased sedimentation rate. 


\section{Regional and Global Correlations}

The Kukkal lacustrine/wetland basin has responded to hydrological changes, principally changes in the amount of precipitation from the SWM, over the 9000 year record presented here. Several other proxy records of similar length are available for comparison in the region of the SWM and the East Asian Monsoon (EAM). Oxygen isotope records from radiometrically-dated speleothems (Cheng et al., 2009; Liu et al., 2013; Fleitmann et al., 2003, 2004, 2007; Morrill et al., 2013a, 2013b) show a general unidirectional decrease in $\delta^{18} \mathrm{O}$ since about 8000 yr BP (Fig. 12). The trend is interpreted by the authors, on the basis of the isotope amount effect, as evidence for a gradual increase in intensity of the SWM and EAM, and is consistent with the unidirectional changes at Kukkal, also interpreted as evidence of an increase in monsoon intensity. Similar unidirectional changes occur in another proxy, the abundance of Globigerina bulloides in seafloor sediment in the Arabian Gulf near Oman (reference). The general increase in SWM rainfall is consistent with the results of Yadava and Ramesh (2005), who interpreted a speleothem record as indicating the highest rainfall around AD 1666 (LIA).

The speoleothem records also show a trough in the $\delta^{18} \mathrm{O}$ between 8500 and $8000 \mathrm{yr}$ BP., interpreted in part as a decrease in monsoon intensity beginning at $8200 \mathrm{yr} \mathrm{BP}$ and lasting 100 to $150 \mathrm{yr}$. An event close to this time is present in the Kukkal sediments at an interpolated age of $8700 \mathrm{yr} \mathrm{BP}$, where it is marked by the replacement of savanna vegetation by grassland assemblage, and inflections in the curves of major oxide abundances. Given the uncertainties of the age interpolation, the proxy records may all be recording the same event. 
At Kukkal, the more pronounced stepwise event between stepwise event between 3000 and 1800 yr BP has no clear counterpart in the speleothem or $G$. bulloides records. Possible counterpart events in climate records from the Indian subcontinent include the pollen-preservation event at 1500 yr BP at Pookode Lake, Kerala (Veena et al., 2014) (discussed above) and a change of slope in a speleothem $\delta^{18} \mathrm{O}$ record from Orissa, India (Yadava and Ramesh, 2005). In the case of the latter, the authors interpret the record as indicating increasing rainfall up until 1500 yr BP, followed by a period of decreasing rainfall that is not evident at Kukkal. A high-rainfall phase at 3000-2300 yr BP is recorded in the discharge of the Indus River (von Rad et al., 1999 a, b). However, this is at variance with a long drought in the Thar Desert, India, between 3600 and 2000 yr BP (Swain et al., 1983; Bryson and Bryson, 1996) or aridity and weakening of the summer monsoon between 4500 and 2000 yr BP in the continental records (Swain et al., 1983).

Climatic events of global scale during the last 3000 yr include the Roman Warm Period (RWP) (2500-1600 yr BP (Wang et al., 2012; Wang et al., 2013), the Medieval Warm Period (MWP, 790-620 yr BP) and the (LIA, 330-80 yr BP) (Bianchi and McCave, 1999). These phenomena have been proposed on the basis of multi-proxy studies in records from higher latitudes, e.g. (Liu et al., 2007, 2013; Zhou et al., 1991, 2011 ; Sukumar et al., 1993, Mazari et al., 1996; Lehmkuhl 1997; von Rad et al., 1999 a, b; Denniston et al., 2000). Crowley and Lowery (2000) described the LIA as a mild cooling event in the Northern Hemisphere. Hu et al., (2001, 2008) determined that the LIA led to $\sim 1.7^{\circ} \mathrm{C}$ of cooling around Alaska (Keigwin, 1996). The LIA, therefore, has a large temporal and spatial variability 
across the globe (IPCC report 2001, ). The stepwise event at 3000 to $1800 \mathrm{yr}$ BP in the Kukkal proxies appear to anticipate the RWP by a few hundred years (Figs. 5 and 9), but the interpolated dates are only approximate; the inflections in the curves may in fact correspond with the initiation of the RWP. There are no events at Kukkal that correspond convincingly to the MWP and the LIA. Even though Zonneveld et al., (1997) suggested a rapid teleconnection between the climates of high latitude and the SWM, the only evidence of such relationships in the Kukkal core is the stepwise event that may correspond to the beginning of the RWM.

\section{A possible scenario for Kukkal}

When comparing and contrasting climatic proxy records from different environments, it must be borne in mind that each environment will have its own set of responses to a particular climatic forcing. Terrestrial records involving plant associations, in particular, may have much longer response times than caves and marine sediments. In the case of the Kukkal record, it is possible to conceive of the evolution of the basin as the protracted response to a century or two of dry climate at about 8000 yr BP, followed by increasing rainfall. Savanna is initially replaced by grassland with palms, sedges and ferns appear later, and all are eventually succeeded by forest in a process that lasts several thousand yr. Evolving vegetation and rainfall amount control weathering, and the character and availability of clastic sediment. Eventual establishment of mature shola forest limits the energy of runoff and the availability of coarser clastics. Pollen preservation is poor following the period of dry climate, and recovers only when the SWM intensity increases more rapidly, augmenting the amount of standing water in the wetland/lake basin. 
The conclusions that emerge from this study are:

i) The Kukkal sediment core contains lacustrine or wetland sediments representing deposition from the Early Holocene (9000 yr BP) to the present Four radiocarbon ages indicate a slow average sedimentation rate of $0.11 \mathrm{~mm} / \mathrm{a}$, except in the upper $14 \mathrm{~cm}$ of core, where the rate was 0.4 $\mathrm{mm} / \mathrm{a}$ or greater. The rate increase may reflect human activity.

ii) Steady unidirectional climate change is indicated by the degree of preservation of organic matter, and by evolution of its composition. Superimposed on this trend are two stepwise changes, at about 8000 and between about 3000 and $1800 \mathrm{yr}$ BP. The former change appears to correspond to a dry spell of 100-150 yr recorded elsewhere in India. The latter corresponds to a local rapid intensification of the SWM, and may correlate with the initiation of the Roman Warm Period. The Medieval Warm Period and the Little Ice Age are not clearly represented in the record.

iii) The $\mathrm{C} / \mathrm{N}$ ratio of Kukkal lake sediments ranges from 14.02 to 8.31 indicating that the organic carbon originates from a mixture of lacustrine algae and vascular plants. Stable carbon isotope data suggest early dominance of $\mathrm{C}_{4}$ plants such as sedges, and a progressive increase in the ratio of $\mathrm{C}_{3}$ to $\mathrm{C}_{4}$ in deposited organic matter.

iv. Chemical weathering indices indicate extreme silicate weathering over the past $9000 \mathrm{yr}$, with a step-wise increase in intensity beginning about 3000 yr BP. Palynological results reveal a succession of vegetation types, beginning with savanna prior to about $8000 \mathrm{yr}$ BP, succeeded by grassland with palms and Asteraceae species. Spore-bearing plants beame abundant just prior to $3200 \mathrm{yr}$ BP and forest was established between 3200 and 1800 yr BP.

\section{REFERENCES}


Achyuthan H, Kar A and Eastoe C (2007a) Late Quaternary environmental changes and evolution of the Tal Chappar salt lakes, Rajasthan. Journal of Paleolimnology 38: 493-507.

Achyuthan H, Quade J, Roe L and Plazeck C (2007b) Stable isotopes of pedogenic carbonates from the eastern margins of the Thar Desert, Rajasthan. Quaternary International 162: 50-60.

Achyuthan H, Nagasundaram M, Gourlan AT, Eastoe C, Ahmad SM, and Veena MP (2014) Mid-Holocene Indian summer monsoon variability off the Andaman Islands, Bay of Bengal. Quaternary International 7: 41-53.

Allchin, B (1997). Origins of a Civilization: The Prehistory and Early Archaeology of South Asia. New York, Viking.

An ZS, Kutzbach JE, Wu XH, Wang SM, Liu XD, Li XQ, Zhou WJ, and Porter SC (2000) Asynchronous Holocene optimum of the East Asian monsoon. Quaternary Science Reviews 19: 743-762.

Anderson DM, Overpeck JT and Gupta AK (2002) Increase in the Asian, Southwest Monsoon during the past four centuries. Science 297 (5581): 596599.

Bagyaraj M and Gurugnanam B (2011) Significance of morphometry studies, soil characteristics, erosion phenomena and landform processes using remote sensing and GIS for Kodaikanal Hills, A global biodiversity hotpot in Western Ghats, Dindigul District, Tamil Nadu, South India. Research Journal of Environmental and Earth Sciences 3(3): 221-233.

Bera SK and Farooqui A (2000) Mid-Holocene vegetation and climate of South Indian Montane. Journal Paleontological Society of India 45: 49-56.

Bianchi GG and McCave IN (1999) Holocene periodicity in North Atlantic climate and deep-ocean flow south of Iceland. Nature 397: 515-517.

Bryson RU and Bryson RA (1996) Application of a global volcanicity timeseries on high-resolution paleoclimatic modeling of the eastern Mediterranean. Water Science and Technology Library31: 1-19.

Carver RE (1971) Procedure in sedimentary petrology, Wiley Interscience, Chicago. 
Chamyal LS, Maurya DM, Bhandari S and Rachna R (2002) Late Quaternary geomorphic evolution of the lower Narmada Valley, western India: implications for neotectonic activity along the Narmada-Son Fault. Geomorphology 46: 177-202.

Chauhan OS and Vogelang A (2006) Climate induced changes in the circulation and dispersal patters of fluvial sources during late Quaternary in the middle Bengal fan. Journal of Earth System Science 115: 379-386.

Chauhan OS, Shiva KP and Suneethi J (2004) Fluvial influx and weathering history of the Himalayas since Last Glacial Maximum - isotopic, sedimentological and magnetic records from the Bay of Bengal. Current Science 87: 509-515.

Chauhan OS, Vogelsang E, Basavaiah N and Syed Abdul Kader U (2010) Reconstruction of the variability of SW monsoon during the past $3 \mathrm{ka}$ from the continental margin of the south eastern Arabian Sea. Journal of Quaternary Science 25(5): 798-807.

Cheng H, Fleitmann D, Edwards LR, Wang X, Cruz FW, Auler AS, Mangini A, Wang Y, Kong X, Burns SJ and Matter A (2009) Timing and structure of the $8.2 \mathrm{kyr}$ BP event inferred from $\delta^{18} \mathrm{O}$ records of stalagmites from China, Oman and Brazil. Geology 37: 1007-1010.

Cronin TM, Dwyer GS, Kamiya T, Schwede S and Willard DA (2003) Medieval Warm Period, Little Ice Age and 20th century temperature variability from Chesapeake Bay. Global Planetary Change 36: 17-29.

Crowley TJ (2000) Causes of climatic change over the past 1000 yr. Science 289: 270-277.

Crowley TJ and Lowery TS (2000) How warm was the medieval warm period? Ambio 29: 51-54.

Denniston RF, Gonzalez LA, Asmerom Y, Sharma RH and Reagan MK (2000) Speleothem evidence for changes in Indian summer monsoon precipitation over the last similar to 2300 yr. Quaternary Research 53:196202.

Duplessy JC (1982) Glacial to interglacial contrast in the northern Indian Ocean. Nature 295: 494-498. 
Duzgoren-Aydin NS, Aydin A and Malpas J (2002) Re-assessment of chemical weathering indices: case study on pyroclastic rocks of Hong Kong. Engineering Geology 63: 99-119.

Engstrom, DR, Wright, HE, Haworth, EY, and Lund, JWG, Jr (Eds.) (1984), Chemical stratigraphy of lake sediments as a record of environmental change in lake sediments and environmental history, Leicester University Press: 1169.

Esper J, Cook ER, and Schweingruber FH (2002a) Low-frequency signals in long tree-ring chronologies and the reconstruction of past temperature variability. Science 295: 2250-2253.

Esper J, Schweingruber FH and Winiger M (2002b) 1300 yr of climatic history for western Central Asia inferred from tree-rings. The Holocene 12: 267-277.

Esper J, Shiyatov SG, Mazepa VS, Wilson RJS, Graybill DA and Funkhouser G (2003) Temperature-sensitive Tien Shan tree ring chronologies show multicentennial growth trends. Climate Dynamics 21: 699-706.

Fægri K and Iversen J (1989) Textbook of pollen analysis. Chichester, UK.

Farooqui A and Sekhar B (2011) Climate change and vegetation succession in Lalitpur area, Uttar Pradesh (India) during late Holocene. Tropical Ecology 52 (1): 69-77.

Farooqui, A, Ray, JG, Farooqui, SA and Khan, ZA 2010, Palynodiversity, sea level and climate prior to $40 \mathrm{ka}$ in Indian Peninsula, Kerala. Quaternary International 213: 2-11.

Fedo CM, Nesbitt HW and Young GM (1995) Unravelling the effects of potassium metasomatism in sedimentary rocks and paleosols, with implications for paleoweathering conditions and provenance. Geology 23: 921-924.

Fleitmann D, Burns SJ, Mudelsee M, Neff U, Kramers J, Mangini A and Matter A (2003) Holocene forcing of the Indian monsoon recorded in a stalagmite from southern Oman. Science 300: 1737 -1739.

Fleitmann D, Burns SJ, Neff U, Mudelsee M, Mangini A and Matter A (2004) Palaeoclimatic interpretation of high-resolution oxygen isotope profiles 
derived from annually laminated speleothems from southern Oman, Quaternary Science Reviews 23: 935-945.

Fleitmann, D, Burns, SJ, Mangini, A, Mudelsee, M, Kramers, J, Villa, I, Neff, Al-Subbary, AA, Buettner, A, Hippler and Matter, A 2007, Holocene ITCZ and Indian monsoon dynamics recorded in stalagmites from Oman and Yemen (Socotra). Quaternary Science Reviews 26: 170-188.

Gaudette H, Flight W, Toner L and Folger D (1974) An inexpensive titration method for the determination of organic carbon in recent sediments. Journal of Sedimentary Petrology 44: 249-253.

Gupta, A K (2004), Origin of agriculture and domestication of plants and animals linked to early Holocene climate amelioration. Current Science, 87 (1): .

Gupta AK, Anderson DM and Overpeck JT (2003) Abrupt changes in Asian southwest monsoon during the Holocene and their links to the North Atlantic Ocean. Nature 421: 354-356.

Gupta AK, Das M and Anderson DM (2005) Solar influence on the Indian summer monsoon during the Holocene. Geophysical Research Letters 32: 2-5

Harnois L (1988) The CIW index: A new chemical index of weathering Sediment. Geology 55: 319-322.

Hu SF, Ito E, Brown TA, Curry BB and Engstrom DR (2001) Pronounced climatic variations in Alaska during the last two millennia. Proceedings of the National Academy of Sciences 98 (19):10552-10556.

Hu C, Henderson GM, Huang J, Xie S, Sun Y and Johnson KR (2008) Quantification of Holocene Asian monsoon rainfall from spatially separated cave records. Earth and Planetary Science Letters 266 (3): 221-232.

IPCC Report (2001) Climate change 2001: The scientific basis. Cambridge University Press, Cambridge.

Keigwin LD (1996) The little ice age and medieval warm period in the Sargasso Sea., Science 274: 1504-1508.

Krishnamurthy TN (1985) Summer monsoon experiment-a review. Monthly Weather Review 113: 1590-1626.

Kudrass HR, Hofman A, Doose H, Emeis K and Erlenkeuser H (2001) Modulation and amplification of climatic changes in the Northern 
Hemisphere by the Indian summer monsoon during the past $80 \mathrm{ky}$. Geology 29: 63-66.

Kumaran KPN, Limaye RB, Nair KM and Padmalal D (2008) Palaeoecological and palaeoclimate potential of subsurface palynological data from the late Quaternary sediments of south Kerala Sedimentary Basin, southwest India. Current Science 95(4): 515-526.

Lehmkuhl F (1997) Late Pleistocene, late glacial and Holocene glacier advances on the Tibetan Plateau. Quaternary International 38/39: 77-83.

Limaye RB, Kumaran KPN, Nair KM and Padmalal D (2010) Cyanobacteria as potential biomarkers of hydrological changes in the late Quaternary sediments of south Kerala Sedimentary Basin, India, Quaternary International 213: 79-90.

Liu YH, Henderson GM, Hu CY, Mason AJ, Charnley N, Johnson KR and Xie SC (2013) Links between the East Asian monsoon and North Atlantic climate during the 8200 year event. Nature Geosciences 6: 117-120.

Loring DH, and Rantala RTT (1992) Manual for the geochemical analyses of marine sediments and suspended particulate matter. Earth Science Reviews 32:235-283.

Lückge AH, Doose-Rolinski AA, Khan H, Schulz H and von Rad H (2001) Monsoonal variability in the northeastern Arabian Sea during the past 5000 yr: geochemical evidence from laminated sediments. Palaeogeography Palaeoclimatology Palaeoecology 167: 273-286.

Mackereth FJH (1966a) In Report, Freshwater Biology Assesment 34: 26-27.

Mackereth FJH (1966b) Some chemical observations on post glacial lake sediments. Philosophical Transactions of the Royal Society of the Biological Sciences 250: 165-213.

Maslov AV, Krupenin MT and Gareev EZ (2003) Lithological, lithochemical, and geochemical indicators of paleoclimate: evidence from riphean of the southern Urals. Lithological Mineral Resource 38: 427-446.

Mayewski PA, Rohling E, Stager JC, Karlen W, Maasch KA, Meeker LD, Meyerson EA, Gasse F, vanKreveld S, Holmgren K, Lee-Thorp J, Rosqvist G, Rack F, Staubwasser M, Schneider RR and Steig EJ (2004) Holocene climate variability. Quaternary Research 62: 243-255. 
Mazari RK, Bagati TN, Chauhan MS and Rajagopalan G (1996) Palaeoclimatic record of last $2000 \mathrm{yr}$ in trans-Himalayan Lahaul-Spiti region. In: Paleoclimate and environmental variability in Austral-Asian transect during the past 2000 years. Proceedings, IGBP-PAGES/PEP II Symposium, Nagoya, Japan: 262-269.

Meher-Homji VM (1967) Phytogeography of a south Indian Hill station, Bull. Torrey Botany Club 94: 230-242.

Meyers PA and Lallier VE (1999) Lacustrine sedimentary organic matter records of late Quaternary paleoclimate. Journal of Paleolimnology 21: 345372.

Minyuk PS, Borkhodoevl VY and Wennrich V (2014) Inorganic geochemistry data from Lake Elgygytgyn sediments: marine isotope stages 611. Climate of the Past 10: 467-485.

Morrill C, Anderson DM, Bauer BA, Buckner R, Gille EP, Gross WS, Hartman M and Shah A (2013a) Proxy benchmarks for intercomparison of 8.2 ka simulations. Climate of the Past 9: 423-432.

Morrill C, LeGrande AN, Renssen H, Bakker P and Otto-Bliesner BL (2013b) Model sensitivity to North Atlantic freshwater forcing at $8.2 \mathrm{ka}$. Climate of the Past 9: 955-968.

Nagasundaram M (2014) Middle to late Holocene paleoenvironmental changes inferred from a marine sediment core off Landfall Island, Bay of Bengal. Unpublished Ph.D Thesis, Anna University, Chennai, India: 136 pp.

Narayana AC, Tiwari, CM, Yadava MG, Nguyen DC, Shen C, Belangaonkar SP and Ramesh R (2011) Stable Isotopic Variations of a Stalagmite from Belum Cave, India: Potential for Monsoon Reconstruction. American Geophysical Union, Fall Meeting, abstract: 31C-1886.

Nesbitt HW and Young GM (1982) Early Proterozoic climates and plate motions inferred from major element chemistry of lutites. Nature 199: 715717.

Overpeck J, Anderson D, Trumbore S and Prell W (1996) The southwest Indian monsoon over the last 18,000 yr. Climate Dynamics 12: 213-225.

Piper CS (1947) Soil and plant analysis, University of Adelaide Press, Adelaide, 368 p. 
Possehl, GL (1996), Mehrgarh, Oxford Companion to Archaeology Brian Fagan, (Ed.)Oxford University Press.

Prell WL and Kutzbach JE (1987) Monsoon variability over the past 150,000 yr. Journal of Geophysical Research 82: 8411-8425.

Prell WL and Van Campo E (1986) Coherent response of Arabian Sea upwelling and pollen transport to late Quaternary monsoonal winds. Nature 323: 526-528.

Price JR and Velbel MA (2003) Chemical weathering indices applied to weathering profiles developed on heterogenous felsic metamorphic parent rocks. Chemical Geology 202:397416.

Rajagopalan G, Ramesh R and Sukumar R (1999) Climatic implications of $\delta^{13} \mathrm{C}$ and $\delta^{18} \mathrm{O}$ ratios from $\mathrm{C}_{3}$ and $\mathrm{C}_{4}$ plants growing in a tropical montane habitat in southern India. Journal of Bioscience 24, 491-498.

Rawat S, Gupta AK, Sangode SJ, Srivastava P and Nainwal HC (2015) Late Pleistocene- Holocene vegetation and Indian summer monsoon record from the Lahaul, northwest Himalaya, India. Quaternary Science Reviews 114: 167-181.

Sant DA, Wadhavan SK, Ganjoo RK and Basavaiah N (2011) Linkage of Proglacial processes from Last glacial to recent inferred form spity sequence, Ley valley, Ladakh Himalaya. Journal of Geological Society of India 74: 147156.

Shah SK, and Bhattacharya A (2009) Tree-ring analysis of sub-fossil woods of Pinus wallichiana from Ziro Valley, Arunachal Pradesh, northeast Himalaya. Journal of Geological Society of India 74: 503-508.

Sharma S, Joachimski MM, Tobschall HJ, Singh IB, Sharma C and Chauhan MS (2006) Correlative evidence of monsoon variability, vegetation change and human habitation in Senai Lake deposit, Ganga plain. Current Science 90: 973-978.

Singhvi AK and Kale VS (2008) Palaeoclimate studies in India: last ice age to the present. IGBP-WCRP-SCOPE Report Series: 4, Indian National Science Academy, New Delhi. 
Sinha A, Cannariato KG, Stott LD, Cheng H, Edwards RL, Yadava MG, Ramesh R and Singh IB (2007) A 900-year (600 to 1500 A.D.) record of the Indian summer monsoon precipitation from the core monsoon zone of India. Geophysical Research Letters 34 (16):1-5.

Sirocko F, Sarnthein M, Erlenkeuser H, Lange H, Arnold M and Duplessy JC (1993) Century scale events in monsoon climate over the past 24,000 yr. Nature 364: 322-324.

Sirocko F, Garbe-Schösnberg D, Mclntyre A and Molfino B (1996) Teleconnections between the subtropical monsoons and high-latitude climates during the last deglaciation. Science 272: 526-529.

Sirocko F, Garbe-Schönberg D and Devey C (2000) Processes controlling trace element geochemistry of Arabian Sea sediments during the last 25,000 yr. Global and Planetary Change 26: 217-303.

Staubwasser M, Sirocko F, Grootes PM and Erlenkeuser H (2002) South Asian monsoon climate change and radiocarbon in the Arabian Sea during early and middle Holocene. Paleoceanography 17 (4): 1063.

Staubwasser M, Sirocko F, Grootes PM and Segl M (2003) Climate change at the $4.2 \mathrm{ka}$ BP termination of the Indus valley civilization and Holocene south Asian monsoon variability. Geophysical Research Letters 30: 1425.

Stuiver M and Reimer PJ (1993) Extended ${ }^{14} \mathrm{C}$ data base and revised CALIB 3.0 ${ }^{14} \mathrm{C}$ age calibration program. Radiocarbon 35: 215-230.

Stuiver M, Reimer PJ and Reimer R (2010) CALIB 5.0.2, WWW program and documentation.

Sukumar R, Ramesh R, Pant RK and Rajagopalan G (1993). A $\delta^{13} \mathrm{C}$ record of late Quaternary climate change from tropical peats in southern India. Nature 364: 703-706.

Sun N and Li XQ (2011) The quantitative reconstruction of the paleoclimate between 5200 and $4300 \mathrm{cal}$ BP in the Tianshui Basin, NW China. Climate of the Past Discussions 7: 2741-2762.

Sun Y, Ding Y and Dai A (2010) Changing links between South Asian summer monsoon circulation and tropospheric land-sea thermal contrasts under a warming scenario. Geophysical Research Letters 37: L02704. 
Swain AM, Kutzbach JE and Hastenrath S (1983) Estimates of Holocene precipitation for Rajasthan, India, based on pollen and lake-level data. Quaternary Research 19:1-17.

Thamban M, Rao, VP and Schneider RR (2002) Reconstruction of late Quaternary monsoon oscillations based on clay mineral proxies using sediment cores from the western margin of India. Marine Geology 186: 527539.

Tiwari M, Ramesh R, Somayajulu BLK, Jull AJT and Burr GS (2005) Solar control of southwest monsoon on centennial time scales. Current Science 89(1): 583-1589.

Tiwari M, Ramesh R, Bhushan R, Somayajulu BLK, Jull AJT and Burr GS (2006) Paleoproductivity variations in the equatorial Arabian Sea: implications for east African and Indian summer rainfalls and the El Nino frequency. Radiocarbon 48:17-29.

Van Campo, E, Cour, P and Hang, S (1996) Holocene environmental changes in Bangong Co basin (western Tibet), Part 2: the pollen records. Paleogeography Paleoclimatology Paleoecology 120: 49-63.

Veena MP, Achyuthan H, Eastoe C and Farooqui A (2014) A multi-proxy reconstruction of monsoon variability in the late Holocene, south India. Quaternary International 325: 63-73.

Verschuren D 2003, Lake-based climate reconstruction in Africa: progress and challenges. Hydrobiologia 500: 315-330.

Verschuren D, Laird KR, and Cumming BF (2000) Rainfall and drought in equatorial east Africa during the past 1100 yr. Nature 403: 410-414.

von Rad, U, Schaaf, M, Michels, KH, Schulz, H, Berger, WH and Sirocko, F (1999a) A 5000-yr record of climate change in varved sediments from the oxygen minimum zone off Pakistan, northeastern Arabian Sea. Quaternary Research 51: 39-53.

von Rad, U, Schulz, H, Riech, V, den Dulk, M, Berner, U and Sirocko, F (1999b) Multiple monsoon controlled breakdown of oxygen-minimum conditions during the past 30,000 yr documented in laminated sediments off Pakistan. Palaeogeography Palaeoclimatology Palaeoecology 152: 129-161.

Wang T, Surge D and Walker KJ (2013) Seasonal climate change across the Roman Warm period/Vandal Minimum transition using isotope 
sclerochronology in archaeological shells and otoliths, southwest Florida, USA. Quaternary International 308-309: 230-241.

Wang T, Surge D and Mithen S (2012) Seasonal temperature variability of the Neoglacial (3300-2500 BP) and Roman Warm Period (2500-1600 BP) reconstructed from oxygen isotope ratios of limpet shells (Patella vulgata), northwest Scotland. Paleogeography Paleoclimatology Paleoecology 317/318:104113.

Wang, Y, Cheng, H, Edwards, RL, He, Y, Kong, X, An, Z, Wu, J, Kelly, MJ, Dykoski, CA and Li, X (2005) The Holocene Asian monsoon: links to solar changes and North Atlantic climate. Science 308: 854-857.

Xia, Yu-mei, and Wang, Pei-fang, (2001) Peat record of climate change for the last $3000 \mathrm{yr}$ in Yangmu, Mishan region of Sanjiang plain. Journal of Geographical Sciences 11(4): 454-460.

Yadav, RR and Singh, J (2002) Tree-ring-based spring temperature patterns over the past four centuries in western Himalaya. Quaternary Research 57: 299-305.

Yadava, MG, and Ramesh, R, (2005) Monsoon reconstruction from radiocarbon dated tropical Indian speleothems. The Holocene 15: 48-59.

YudovichYE and Ketris MP (2006) Selenium in coal: a review. International Journal of Coal Geology 67 (2006), pp. 112-126.

Zhou, WJ, An, ZS, Head, J, Donhaue, DJ, Ren, JZ, Lin, BH, Zhou, MF, Yan, YS, and Zhang, JZ (1991) ${ }^{14} \mathrm{C}$ dating and measurements of climatic proxy indices of loess sequence to record paleomonsoon variation on the Loess Plateau of China during the last 16000 yr (abstr). Radiocarbon 33: 259.

Zhou T, Li B, Man W, Zhang L and Zhang J (2011) A comparison of the Medieval Warm Period, Little Ice Age and 20th century warming simulated by the FGOALS climate system model, Chinese Science Bulletin 56 (28): 3028-3041.

Zonneveld, KAF, Ganssen, G, Troelstra, S, Versteegh, GJM and Visscher, H (1997) Mechanisms forcing abrupt fluctuations of the Indian Ocean summer monsoon during the last deglaciation. Quaternary Science Reviews 16: 187201. 


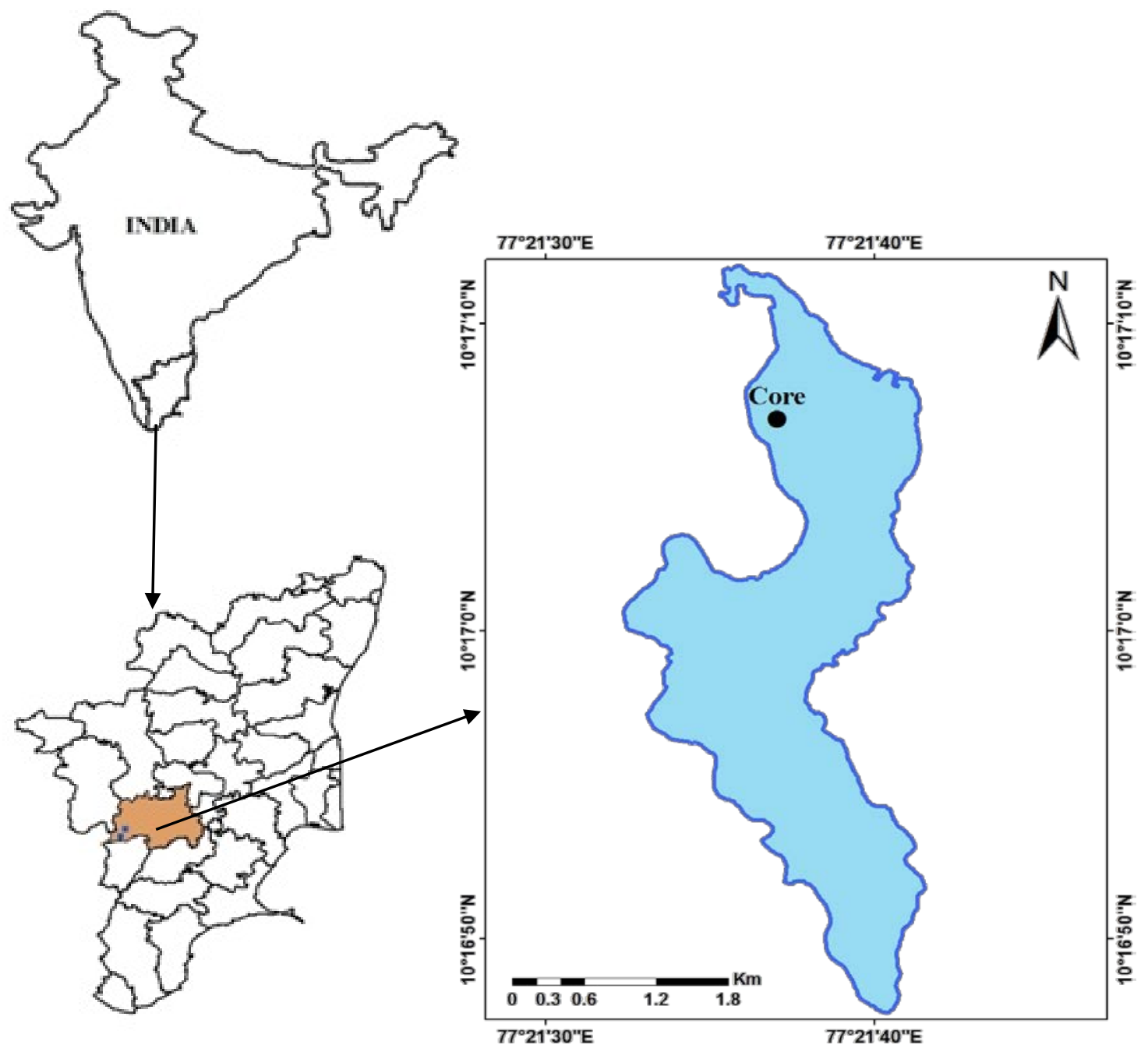

Figure 1 Location map of Kukkal Lake and the coring site. 


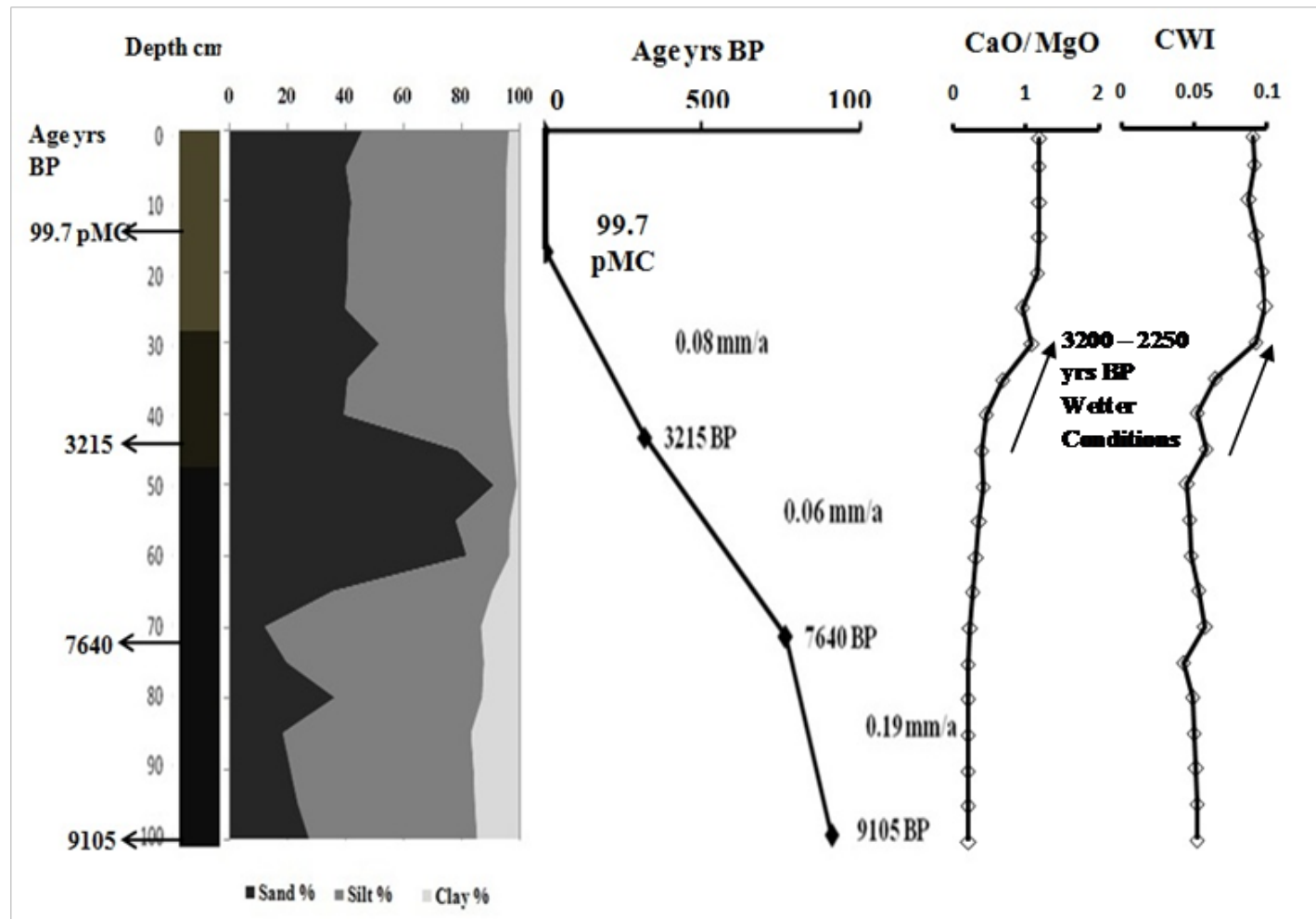

Figure 2. Sediment core texture, radiocarbon ages, sedimentation rate, $\mathrm{CaO} / \mathrm{MgO}$ and CWI variation with depth. 


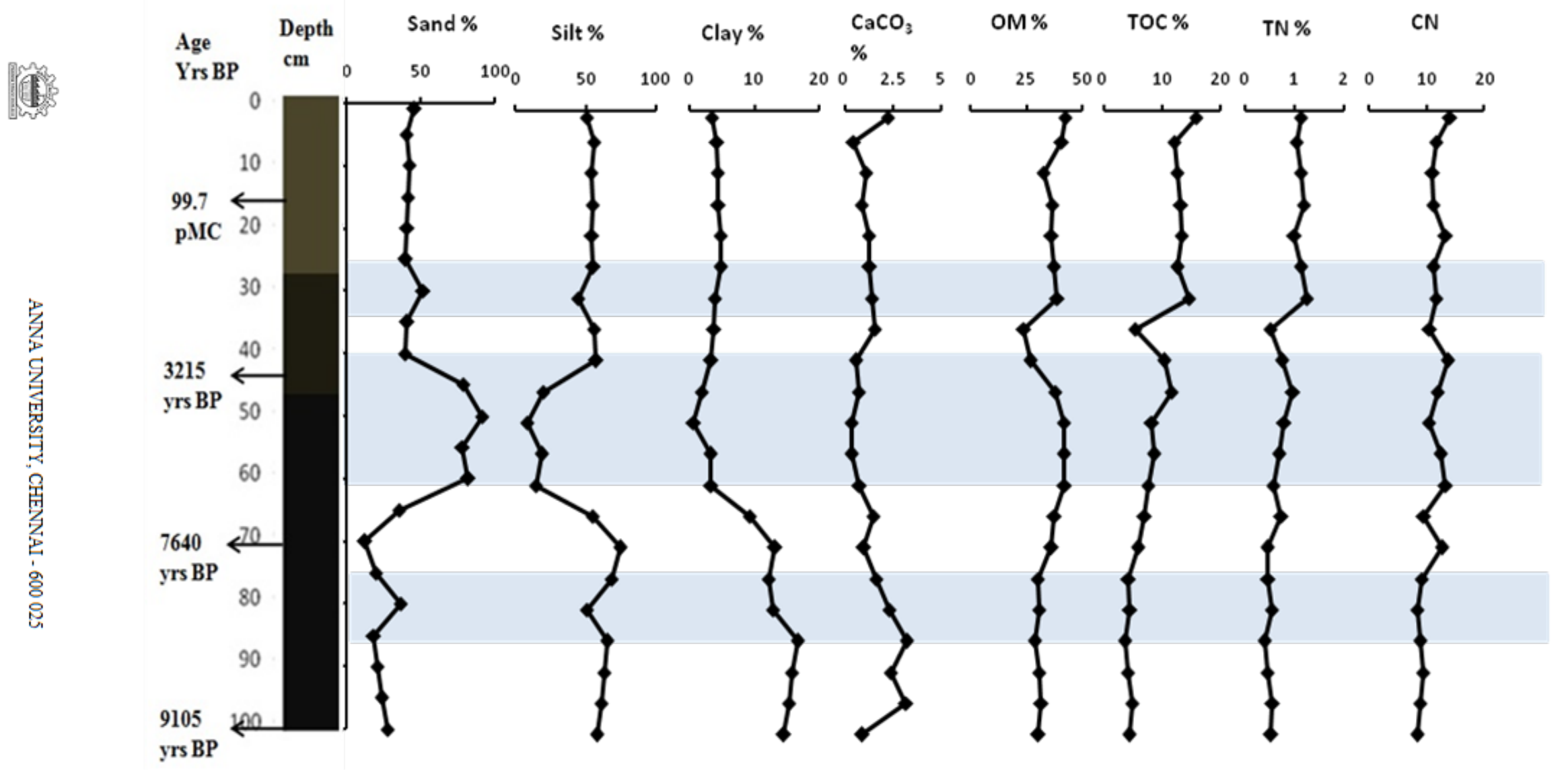

Figure 3. Down sediment core variations of texture, $\mathrm{OM}$, TOC, TN percentage and $\mathrm{C} / \mathrm{N}$ ratio. 


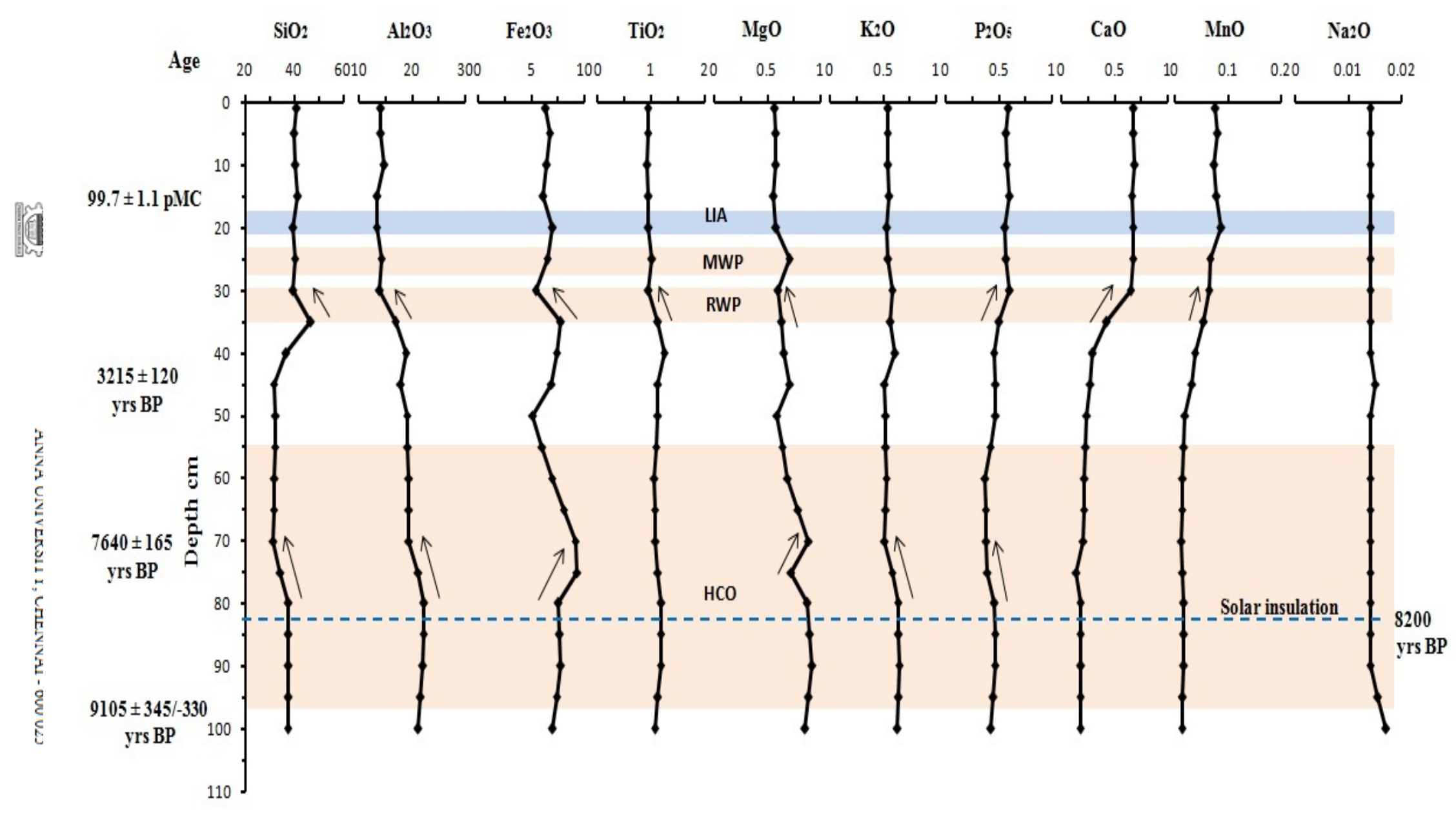

Figure 4 Depth versus major oxide variation observed in the sediment core 


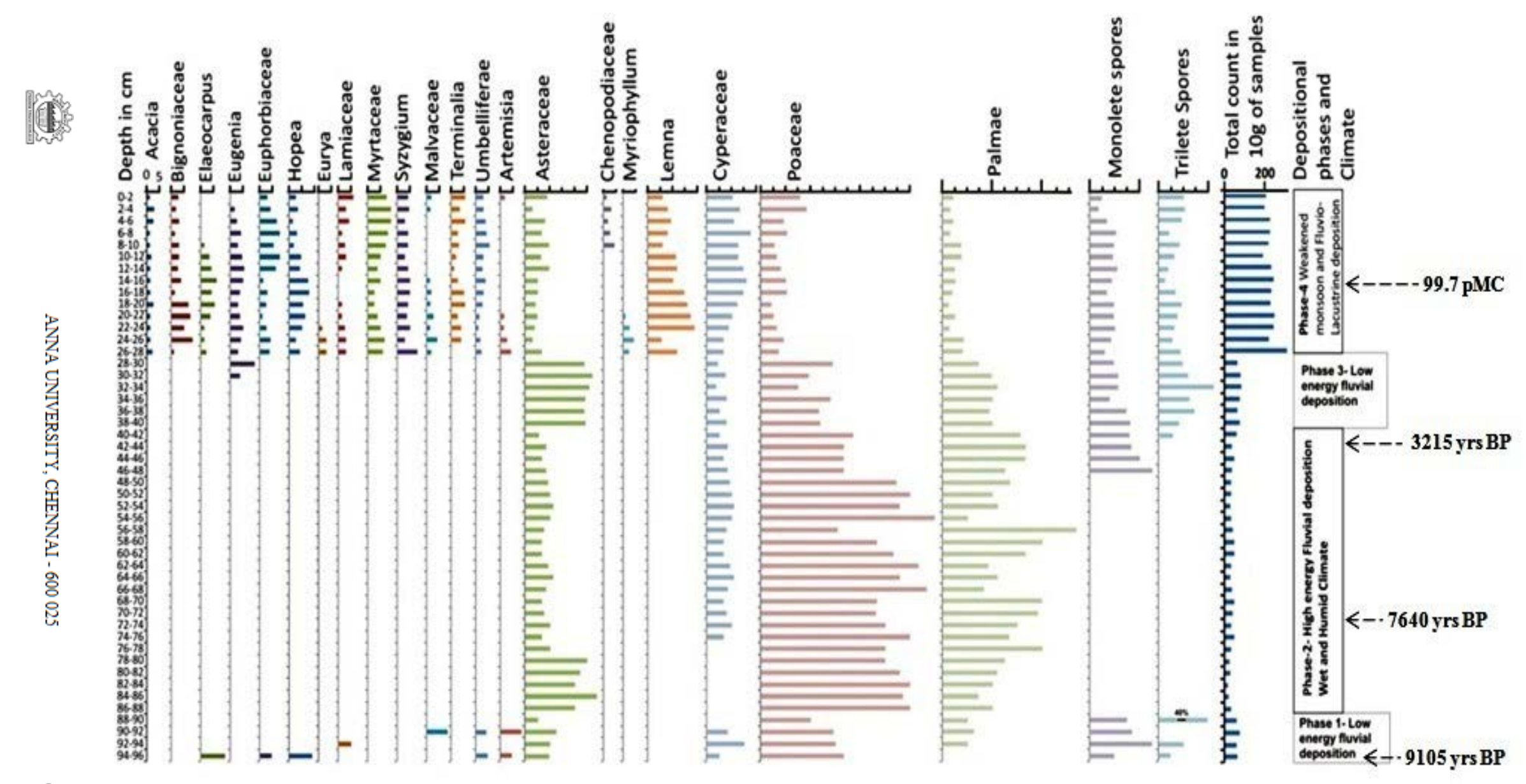

(2)

Figure 10. Pollen spectrum of sediment core. Note that there is a significant shift in the abundance of Poaceae, Cyperaceae and Palmae 


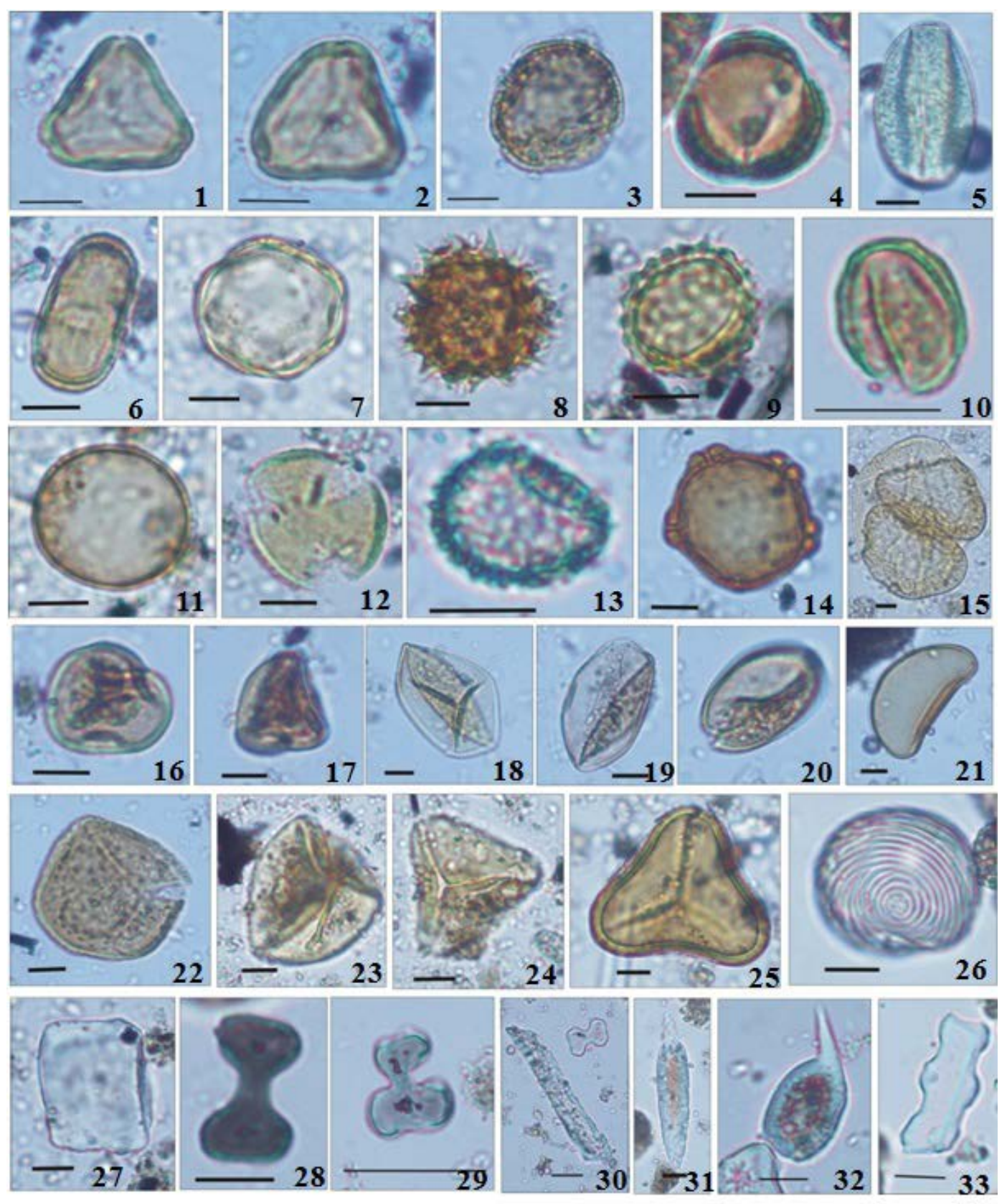

Figure 11 Pollen forms identified in palynological assemblage.

1.Syzygium; 2 Eugenia; 3 Euphorbiaceae; 4 Artemisia; 5 Bignoniceae; 6 Umbellifera; 7 Terminalia; 8 and9 Asteraceae; 10 Eurya; 11 Moraceae; 12 Hopea; 13 Lemna; 14 Myriophyllum; 15 Pinus; 16-17 Cyperaceae; 18-19 Poaceae; 20 Palmae; 21 Monolete; 22-25 Trilete spores; 26 Pseudoschizae; 27 Bulliform Phytolith; 28-29 Dumbell shaped phytolith; 30 Phytolith; 31-32 Spiny phytolith of grass; 33 phytolith. 


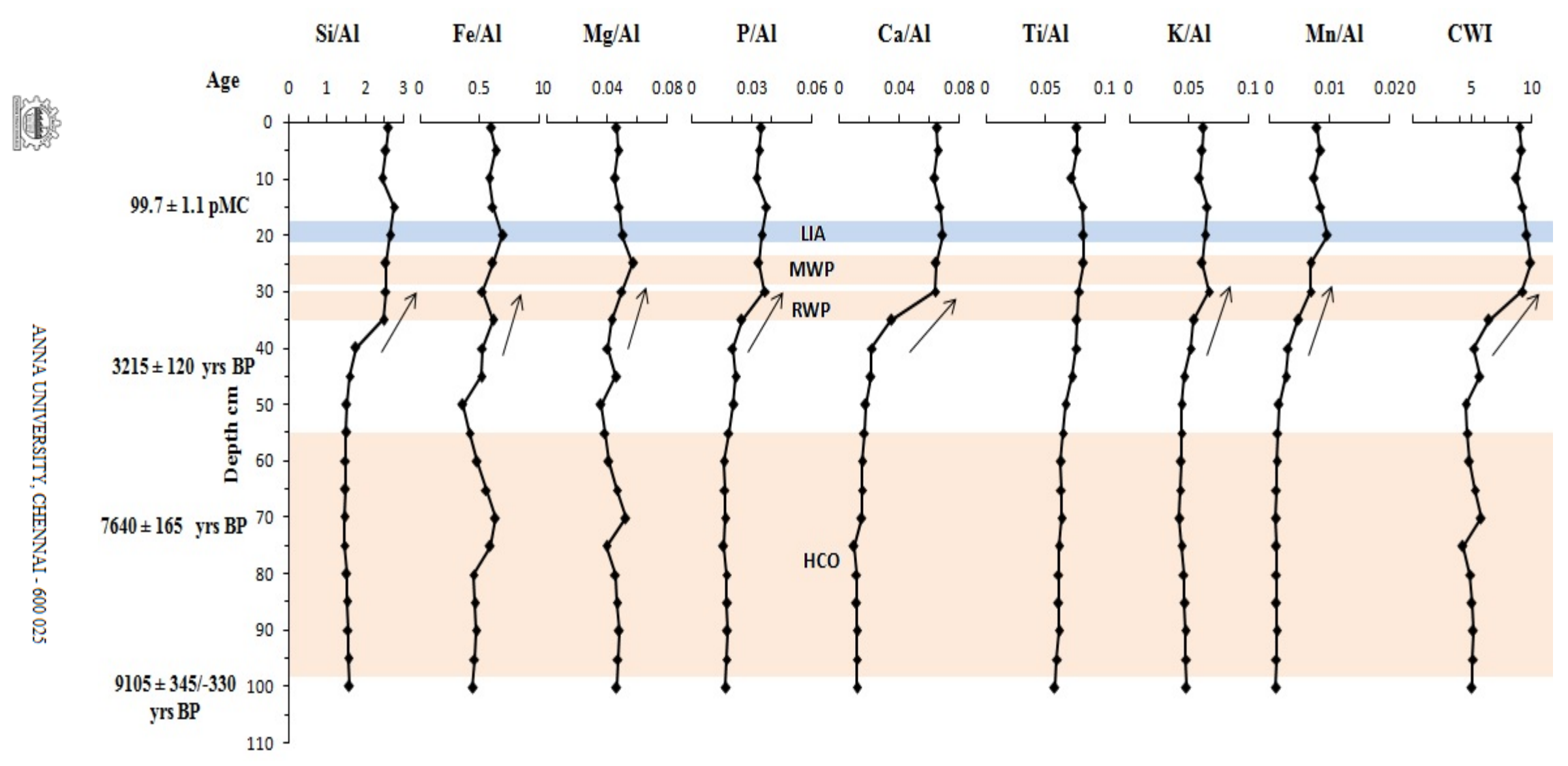

Figure 5. Down sediment core variations of major elements normalized by Al and CWI values. 


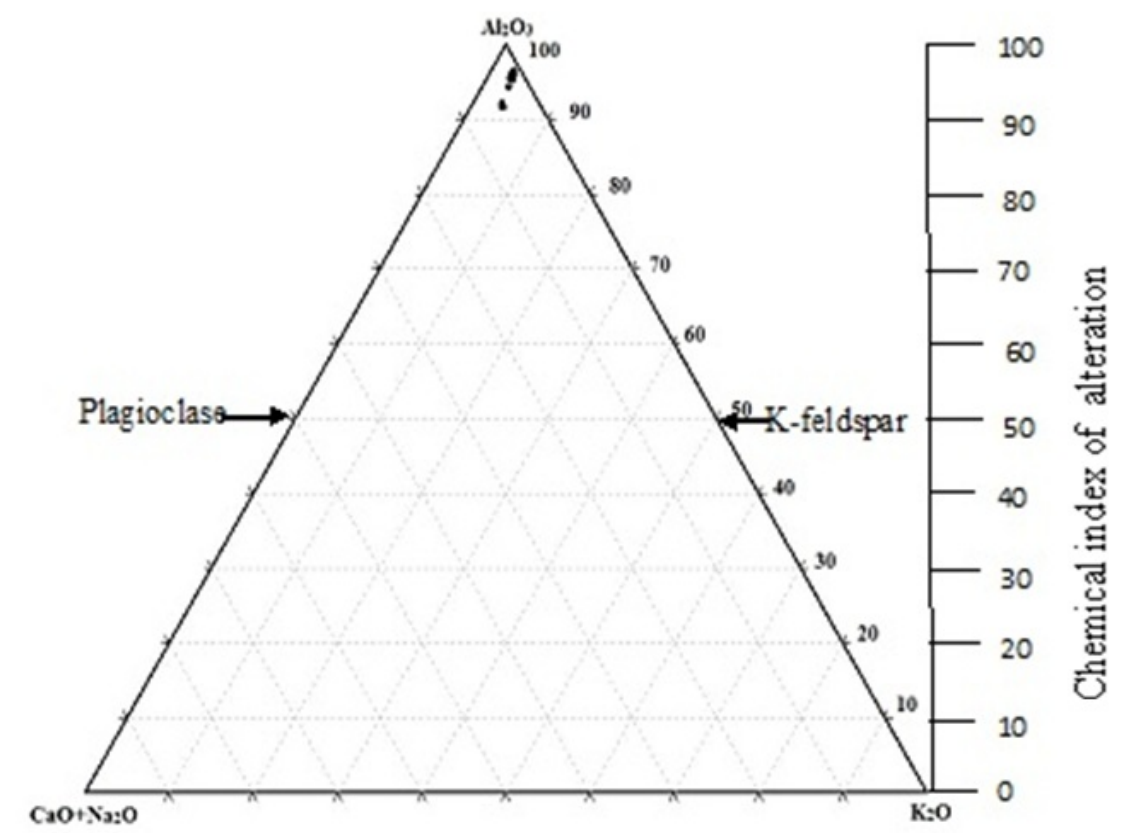

Figure 6 Ternary diagram showing weathering trend of sediement using $\mathrm{Al}_{2} \mathrm{O}_{3}-\left(\mathrm{CaO}+\mathrm{Na}_{2} \mathrm{O}\right)-\mathrm{K}_{2} \mathrm{O}$ diagram
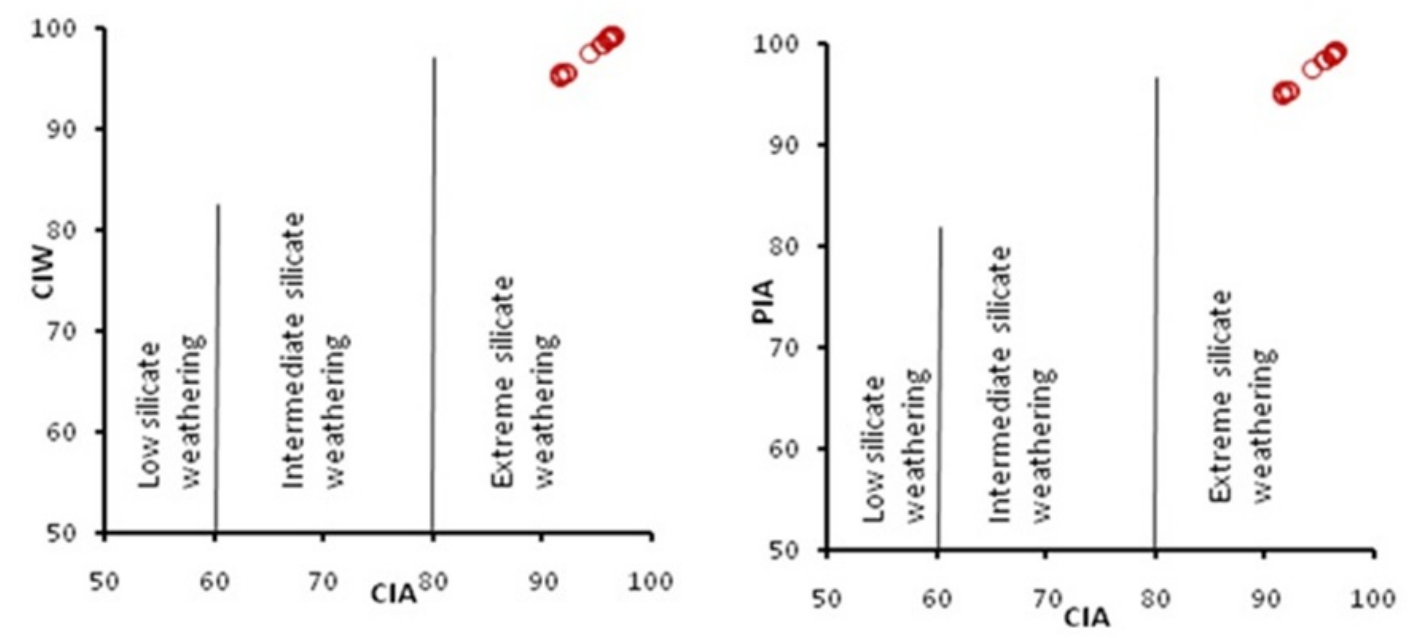

Figure 8 a, b Scatter plots of CIA vs. CIW and PIA of sediment core 


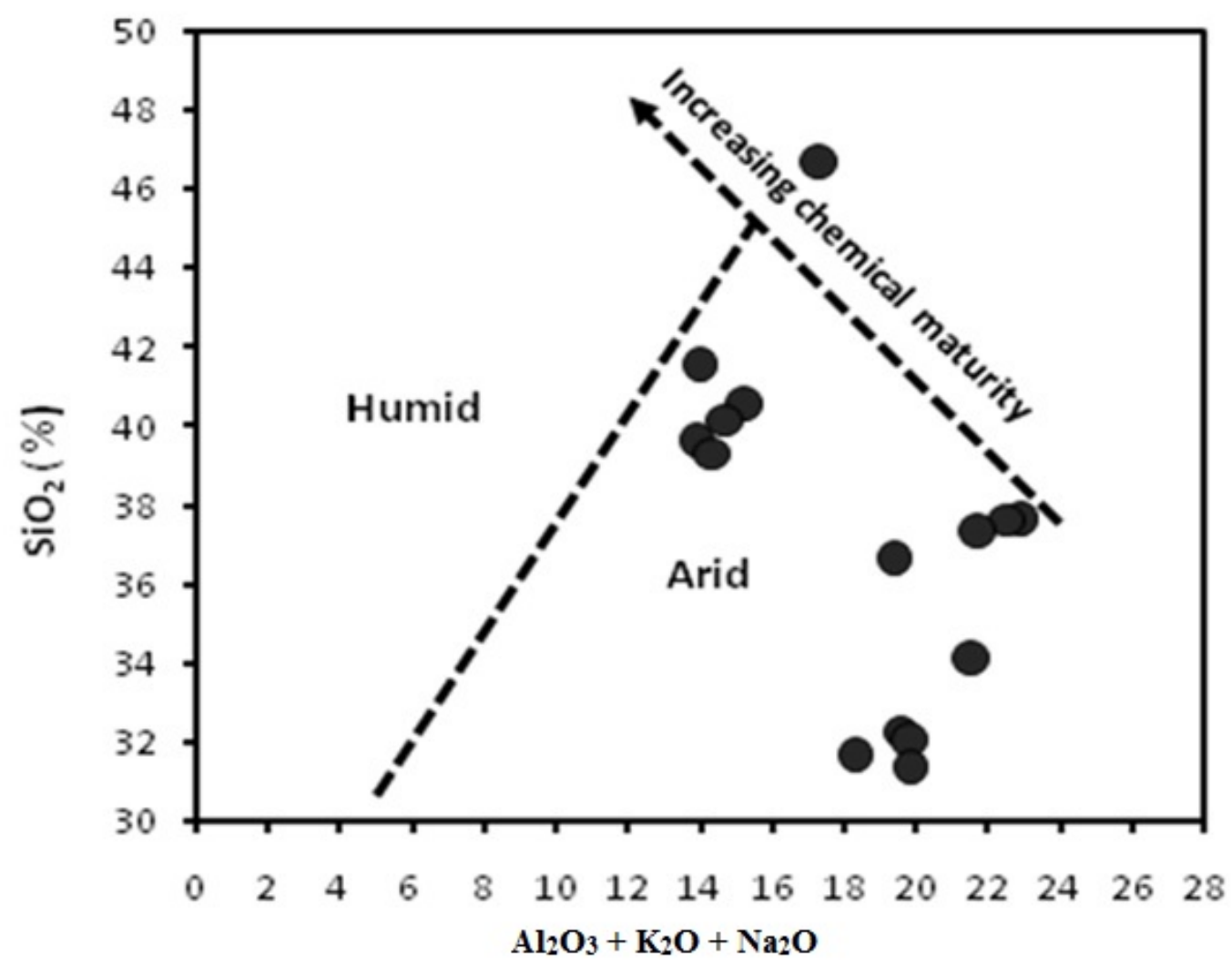

Figure 7. Paleoenvironment discrimination of sediment core exhibiting deposition of highly weathered sediments in arid and dry conditions. 


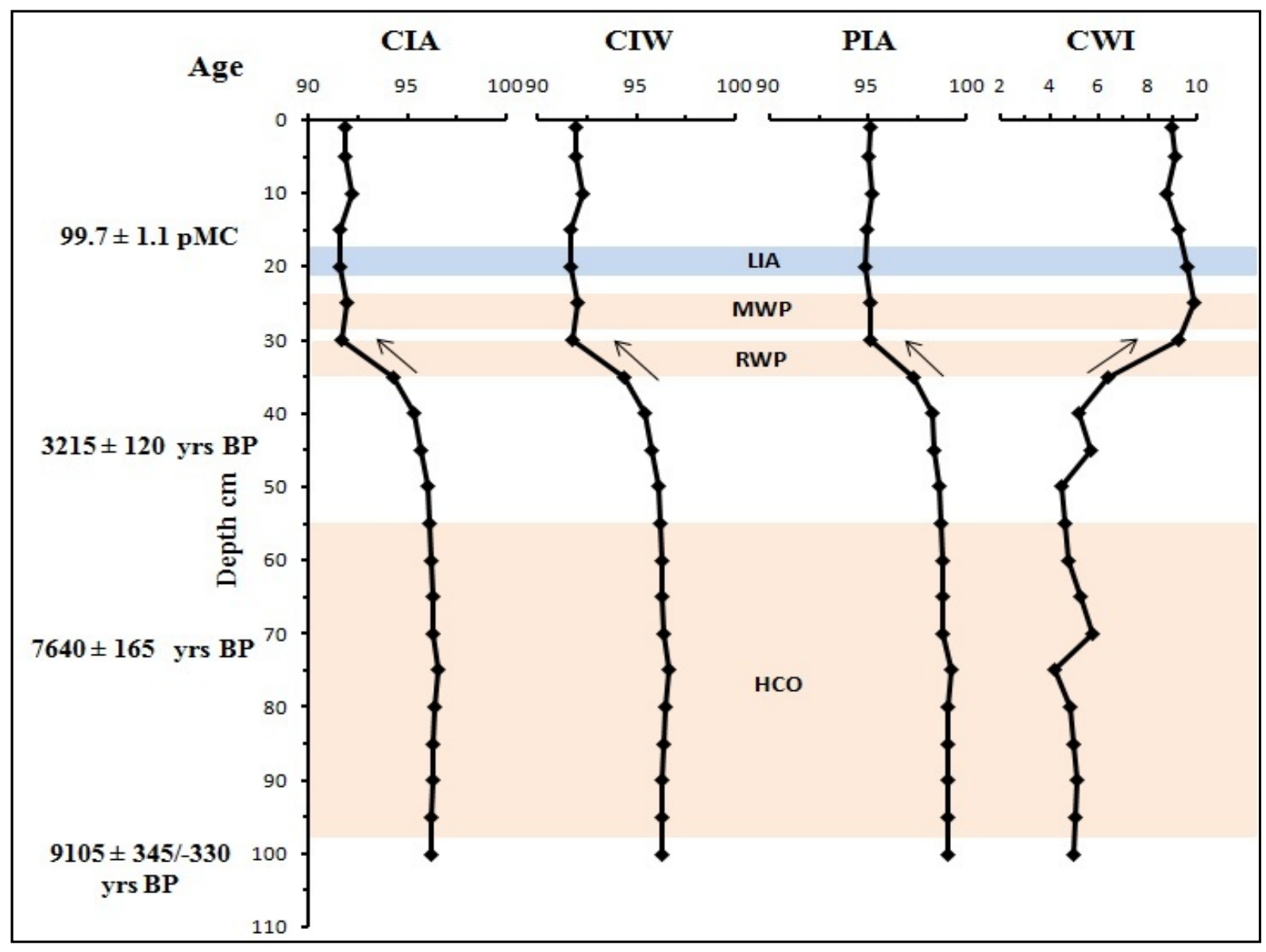

Figure 9. Down sediment core variations showing CIA, CIW, PIA and CWI values

Since the last 9200 yr BP. 


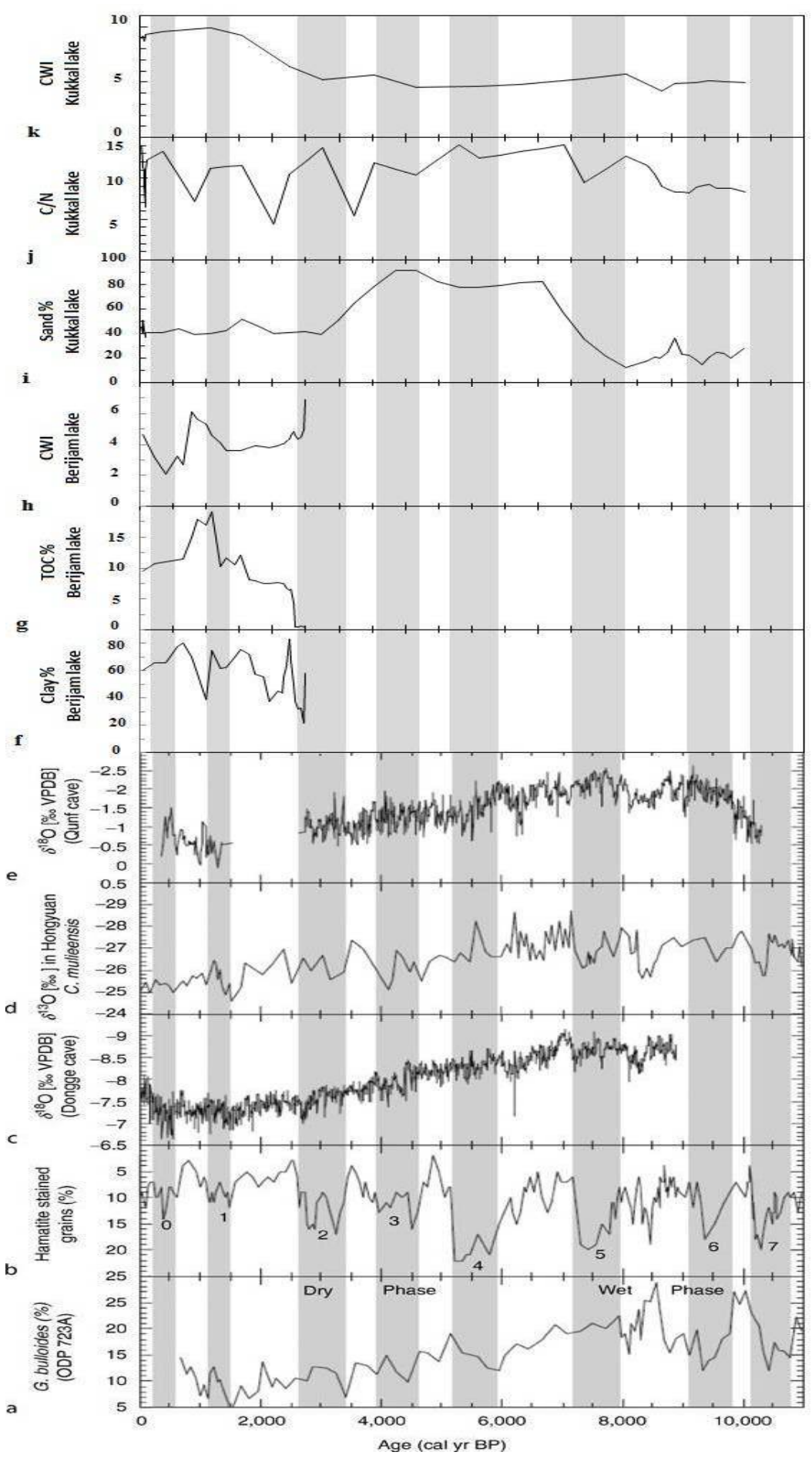

Figure 12 A comparison of various proxies and geochemical data patterns as observed from various sites such as ODP site 723A (G. bulloides \%) Arabian Sea, Hematite\% (in MC52-VM29-191) from North Atlantic site, $\delta^{18} \mathrm{O} \%$ (Dongee Cave), $\delta^{18} \mathrm{O} \%$ (Hongyuan site), Qunf cave site, Berijam and Kukkal parameters (after Bond et al., 2001 and Gupta et al., 2003). Vertical grey bars indicate periods of weak SWM. 
Table 1. Lithology of the Kukkal lake sediment core

\begin{tabular}{|c|l|c|}
\hline $\begin{array}{c}\text { Litho unit } \\
\text { (Depth cm) }\end{array}$ & \multicolumn{1}{|c|}{ Description } & \multicolumn{1}{|c|}{ Munsells color } \\
\hline III (28-0) $)$ & $\begin{array}{l}\text { Brownish black (10 Y 3/1) in colour and the } \\
\text { sediment type was sandy silt and silty sand } \\
\text { laminae, with the coarse organic carbon } \\
\text { pellets with rootlets and root pores. }\end{array}$ & Brownish black 10 YR 3/1 \\
\hline II (47-28) & $\begin{array}{l}\text { brownish black (10 Y 2/3) in colour } \\
\text { moderately sorted sandy silt and silty sand } \\
\text { quartz, fine clear coarse quartz, angular to sub } \\
\text { angular with ferruginous nodules, and peat } \\
\text { 3.5 mm in length }\end{array}$ & Brownish black 10 YR/2/3 \\
\hline I (100-47) & $\begin{array}{l}\text { Peaty layer, dark black, clay with few roots, } \\
\text { organic rich layer, fine sandy silt, clayey silt } \\
\text { and silty sand layers }\end{array}$ & Black 10YR 2/1 \\
\hline
\end{tabular}

Table 2. Radiocarbon dates of the lake sediment core collected from the Kukkal lake

\begin{tabular}{|c|c|c|c|c|c|}
\hline S.No & Lab ID & Depth $\mathbf{( c m )}$ & $\begin{array}{c}\mathbf{1 4}^{\mathbf{C}} \mathbf{C a g} \\
\mathbf{( y r} \mathbf{B P})\end{array}$ & Calibrated date & $\boldsymbol{\delta}^{\mathbf{1 3}} \mathbf{C \% o}$ \\
\hline $\mathbf{1}$ & & & & & -22.6 \\
\hline 2 & A16345 & $16-18$ & $99.7 \pm 1.1 \mathrm{pMC}$ & AD 1650 - 1955 & -23.3 \\
\hline 3 & & & & & -22.8 \\
\hline 4 & A16346 & $42-44$ & $3215 \pm 120$ & $1862-1131$ BC & -20.6 \\
\hline 5 & A16347 & $70-72$ & $7640 \pm 165$ & $7028-6110$ BC & -17.7 \\
\hline 6 & A16311 & $98-100$ & $9105 \pm 345 /-330$ & $9255-7526$ BC & -16.1 \\
\hline
\end{tabular}


Table 3. Sediment texture, OM, TOC, TN content, $\mathrm{C} / \mathrm{N}$ ratio and age of Kukkal sediment core

\begin{tabular}{|c|c|c|c|c|c|c|c|c|c|c|c|}
\hline S.No & Depth (cm) & Age & Sand \% & Silt \% & Clay \% & $\mathrm{CaCO}_{3} \%$ & OM \% & TOC \% & TN \% & $\mathrm{C} / \mathrm{N}$ & Sediment type \\
\hline 1 & $2-4$ & 17.58 & 45.75 & 50.72 & 3.53 & 2.25 & 42.34 & 15.79 & 1.13 & 14.02 & Sandy silt \\
\hline 2 & $4-6$ & 29.30 & 40.11 & 55.61 & 4.27 & 0.48 & 40.86 & 12.13 & 1.04 & 11.62 & Sandy silt \\
\hline 3 & $6-8$ & 41.02 & 50.61 & 45.49 & 3.90 & 1.32 & 47.02 & 12.34 & 1.09 & 11.32 & Silty sand \\
\hline 4 & $8-10$ & 52.74 & 41.98 & 53.57 & 4.46 & 1.10 & 32.70 & 12.54 & 1.14 & 11.01 & Sandy silt \\
\hline 5 & $10-12$ & 64.46 & 42.23 & 53.39 & 4.39 & 1.17 & 34.77 & 10.29 & 1.19 & 8.73 & Sandy silt \\
\hline 6 & $12-14$ & 76.18 & 36.98 & 58.00 & 5.02 & 0.93 & 34.89 & 8.05 & 1.25 & 6.45 & Sandy silt \\
\hline 7 & $14-16$ & 87.90 & 41.00 & 54.50 & 4.50 & 0.90 & 36.64 & 13.19 & 1.18 & 11.15 & Sandy silt \\
\hline 8 & $16-18$ & 99.70 & 40.83 & 53.99 & 5.17 & 1.40 & 35.11 & 13.20 & 1.09 & 12.21 & Sandy silt \\
\hline 9 & $18-20$ & 339.34 & 40.87 & 54.33 & 4.81 & 1.25 & 36.30 & 13.21 & 1.00 & 13.28 & Sandy silt \\
\hline 10 & $20-22$ & 578.98 & 44.20 & 51.30 & 4.50 & 1.16 & 36.17 & 10.53 & 1.04 & 10.25 & Sandy silt \\
\hline 11 & $22-24$ & 818.62 & 39.02 & 56.40 & 4.58 & 1.19 & 35.38 & 7.85 & 1.09 & 7.22 & Sandy silt \\
\hline 12 & $24-26$ & 1058.25 & 39.88 & 55.26 & 4.86 & 1.29 & 37.15 & 12.54 & 1.12 & 11.19 & Sandy silt \\
\hline 13 & $26-28$ & 1297.89 & 42.66 & 53.02 & 4.31 & 1.59 & 36.45 & 13.49 & 1.18 & 11.39 & Sandy silt \\
\hline 14 & $28-30$ & 1537.53 & 51.73 & 44.26 & 4.01 & 1.38 & 38.93 & 14.45 & 1.25 & 11.59 & Silty sand \\
\hline 15 & $30-32$ & 1777.17 & 46.24 & 49.67 & 4.09 & 0.76 & 32.95 & 8.60 & 0.93 & 8.02 & Sandy silt \\
\hline 16 & $32-34$ & 2016.81 & 39.73 & 56.40 & 3.87 & 1.16 & 22.48 & 2.76 & 0.62 & 4.45 & Sandy silt \\
\hline 17 & $34-36$ & 2256.45 & 40.75 & 55.42 & 3.83 & 1.57 & 23.97 & 5.35 & 0.51 & 10.52 & Sandy silt \\
\hline 18 & $36-38$ & 2496.08 & 41.26 & 55.47 & 3.27 & 0.19 & 24.58 & 7.83 & 0.63 & 12.12 & Sandy silt \\
\hline 19 & $38-40$ & 2735.72 & 39.49 & 57.15 & 3.36 & 0.57 & 26.81 & 10.30 & 0.75 & 13.72 & Sandy silt \\
\hline 20 & $40-42$ & 2975.36 & 50.66 & 46.01 & 3.33 & 0.53 & 30.97 & 7.94 & 0.89 & 9.56 & Silty sand \\
\hline 21 & $42-44$ & 3215.00 & 64.97 & 32.41 & 2.62 & 0.55 & 34.74 & 5.58 & 1.03 & 5.41 & Silty sand \\
\hline 22 & $44-46$ & 3531.07 & 78.47 & 19.55 & 1.98 & 0.72 & 37.81 & 11.50 & 0.97 & 11.86 & Sand \\
\hline 23 & $46-48$ & 3847.14 & 91.92 & 7.56 & 0.52 & 0.63 & 40.04 & 9.86 & 0.88 & 11.13 & Sand \\
\hline 24 & $48-50$ & 4163.21 & 91.29 & 7.97 & 0.74 & 0.36 & 41.56 & 8.22 & 0.79 & 10.40 & Sand \\
\hline 25 & $50-52$ & 4479.29 & 82.66 & 14.65 & 2.69 & 0.57 & 42.72 & 8.57 & 0.71 & 12.23 & Sand \\
\hline 26 & $52-54$ & 4795.36 & 77.90 & 18.83 & 3.27 & 0.59 & 42.18 & 8.92 & 0.63 & 14.07 & Sand \\
\hline 27 & $54-56$ & 5111.43 & 78.02 & 18.76 & 3.22 & 0.36 & 41.68 & 8.61 & 0.69 & 12.43 & Sand \\
\hline
\end{tabular}


Table 3. (Continued)

\begin{tabular}{|c|c|c|c|c|c|c|c|c|c|c|c|}
\hline S.No & Depth (cm) & Age & Sand \% & Silt \% & Clay \% & $\mathbf{C a C O}_{\mathbf{3}} \mathbf{\%}$ & $\mathbf{O M}$ \% & TOC \% & TN \% & C/N & Sediment type \\
\hline 28 & $56-58$ & 5427.50 & 78.91 & 17.91 & 3.18 & 1.00 & 42.20 & 8.13 & 0.63 & 12.84 & Sand \\
\hline 29 & $58-60$ & 5743.57 & 81.84 & 14.80 & 3.36 & 0.78 & 42.02 & 7.64 & 0.58 & 13.25 & Sand \\
\hline 30 & $60-62$ & 6059.64 & 82.38 & 13.63 & 4.00 & 0.76 & 40.65 & 7.57 & 0.55 & 13.66 & Sand \\
\hline 31 & $62-64$ & 6375.71 & 57.92 & 34.06 & 8.02 & 0.77 & 38.85 & 7.50 & 0.53 & 14.07 & Silty sand \\
\hline 32 & $64-66$ & 6691.79 & 35.73 & 54.99 & 9.28 & 1.48 & 37.55 & 6.96 & 0.73 & 9.50 & Sandy silt \\
\hline 33 & $66-68$ & 7007.86 & 21.26 & 67.64 & 11.10 & 0.98 & 36.20 & 6.39 & 0.60 & 11.10 & Sandy silt \\
\hline 34 & $68-70$ & 7323.93 & $\mathbf{1 2 . 2 5}$ & $\mathbf{7 4 . 5 6}$ & 13.20 & 1.00 & 36.25 & 5.82 & 0.46 & 12.70 & Clayey silt \\
\hline 35 & $70-72$ & $\mathbf{7 6 4 0 . 0 0}$ & 17.91 & 69.41 & 12.68 & 1.67 & 31.80 & 5.49 & 0.47 & 11.61 & Sandy silt \\
\hline 36 & $72-74$ & 7744.64 & 20.52 & 67.08 & 12.40 & 1.00 & 31.67 & 5.16 & 0.49 & 10.52 & Sandy silt \\
\hline 37 & $74-76$ & 7849.29 & 19.68 & 68.12 & 12.20 & 1.64 & 30.06 & 4.25 & 0.47 & 9.03 & Sandy silt \\
\hline 38 & $76-78$ & 7953.93 & 24.78 & 61.25 & 13.96 & 2.44 & 30.96 & 4.38 & 0.51 & 8.69 & Sandy silt \\
\hline 39 & $78-80$ & 8058.57 & 36.44 & 50.75 & 12.81 & 2.28 & 30.71 & 4.51 & 0.54 & 8.34 & Sandy silt \\
\hline 40 & $80-82$ & 8163.21 & 23.12 & 60.79 & 16.09 & 2.38 & 32.14 & 4.51 & 0.55 & 8.28 & Sandy silt \\
\hline 41 & $82-84$ & 8267.86 & 22.61 & 63.39 & 14.01 & 2.79 & 32.27 & 4.52 & 0.55 & 8.21 & Sandy silt \\
\hline 42 & $84-86$ & 8372.50 & 18.41 & 64.90 & $\mathbf{1 6 . 6 9}$ & 3.19 & 28.69 & 3.58 & $\mathbf{0 . 4 0}$ & 8.89 & Sandy silt \\
\hline 43 & $86-88$ & 8477.14 & 14.97 & 69.91 & 15.12 & 2.79 & 29.74 & 3.86 & 0.42 & 9.10 & Clayey silt \\
\hline 44 & $88-90$ & 8581.79 & 20.99 & 63.20 & 15.81 & 2.40 & 30.80 & 4.15 & 0.45 & 9.30 & Sandy silt \\
\hline 45 & $90-92$ & 8686.43 & 24.33 & 61.45 & 14.22 & 2.46 & 32.17 & 4.91 & 0.56 & 8.77 & Sandy silt \\
\hline 46 & $92-94$ & 8791.07 & 23.57 & 61.10 & 15.33 & 3.16 & 31.62 & 4.90 & 0.56 & 8.76 & Sandy silt \\
\hline 47 & $94-96$ & 8895.71 & 19.65 & 64.20 & 16.15 & $\mathbf{4 . 0 8}$ & 30.10 & 4.90 & 0.56 & 8.75 & Sandy silt \\
\hline 48 & $98-100$ & $\mathbf{9 1 0 5 . 0 0}$ & 27.50 & 57.93 & 14.57 & 0.92 & 30.28 & 4.42 & 0.53 & 8.31 & Sandy silt \\
\hline & Average & $\mathbf{4 3 . 8 7}$ & $\mathbf{4 8 . 7 7}$ & $\mathbf{7 . 3 6}$ & $\mathbf{1 . 3 7}$ & $\mathbf{3 4 . 8 7}$ & $\mathbf{8 . 0 7}$ & $\mathbf{0 . 7 7}$ & $\mathbf{1 0 . 4 4}$ \\
\hline
\end{tabular}

Ages: measured interpolated

Compositions: Maximum bold, minimum bold 
Table 4. Major Oxides (\%) and weathering index of the sediments from the Kukkal sediment core

\begin{tabular}{|c|c|c|c|c|c|c|c|c|c|c|c|c|c|c|c|c|}
\hline S.No & m) & Age & $\mathrm{SiO}_{2}$ & $\mathrm{Al}_{2} \mathbf{O}_{3}$ & $\mathrm{Fe}_{2} \mathrm{O}_{3}$ & $\mathrm{TiO}_{2}$ & MgO & $\mathrm{K}_{2} \mathrm{O}$ & $\mathbf{P}_{2} \mathbf{O}_{5}$ & $\mathrm{CaO}$ & MnO & $\mathrm{Na}_{2} \mathrm{O}$ & CIA & IW & PIA & CWI \\
\hline 1 & $2-4$ & 17.58 & 41.01 & 14.06 & 6.29 & 0.94 & 0.57 & 0.55 & 0.59 & 0.68 & 0.08 & 0.01 & 91.88 & 1.96 & 95.13 & 8.99 \\
\hline 2 & & & & 14.02 & 71 & 94 & & & & & & & & & & 14 \\
\hline 3 & & 52.74 & .52 & 14.73 & 46 & 0.93 & 58 & 55 & .58 & 69 & 07 & & & .25 & 5.27 & .73 \\
\hline 4 & & 87.90 & 41.50 & 13.39 & 6.13 & 0.95 & & .56 & 0.60 & & & & & & & \\
\hline 5 & & 23924 & & 13.31 & .95 & 0.95 & 59 & .54 & 0.56 & & & & & & 1.87 & \\
\hline 6 & 2 & 58.25 & 40.18 & 14.14 & 6.47 & 1.01 & 0.71 & 0.55 & 0.57 & .68 & .07 & & & 2.05 & 95.17 & 9.90 \\
\hline 7 & & 33 & 9.35 & 13.77 & 5.38 & 0.94 & 0.60 & .58 & 0.61 & & & & & & 19 & 21 \\
\hline 8 & & & 46.65 & 16.77 & 7.75 & 1.13 & 63 & 0.57 & 0.50 & & & & & & 97.34 & \\
\hline 9 & 3 & & 36.65 & 18.73 & 7.38 & 1.25 & 0.66 & 0.61 & 0.46 & & & & 95.31 & 38 & 98.31 & 19 \\
\hline 10 & & & 31.66 & 17.73 & 6.87 & 1.13 & 0.71 & 0.52 & 0.47 & & 3 & & & & 98.34 & 66 \\
\hline 11 & 4 & 1 & 32.30 & 19.01 & 5.09 & 1.12 & 0.60 & 0.53 & 0.47 & & 02 & & 96.03 & .10 & 98.61 & 4.50 \\
\hline 12 & & & & & & & 0.64 & & 0.42 & & & & & & 98.70 & \\
\hline 13 & & & 32.01 & 19.31 & 6.5 & 1.06 & 0.69 & 0.53 & 0.37 & & 01 & & 20 & & 98.79 & 4.77 \\
\hline 14 & & & & & 8.03 & 1.07 & 0.79 & 0.52 & 0.38 & & & & 96.26 & & 98.80 & 5.26 \\
\hline 15 & 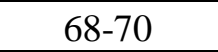 & 3 & 31.35 & 19.28 & 9.14 & 1.08 & 0.89 & 0.51 & 0.38 & 1 & 01 & 1 & 96.33 & 96.39 & 98.82 & .75 \\
\hline 16 & & & 34.11 & 21.00 & 9.30 & & & 0.58 & 0.39 & & & & 96.58 & 96.64 & 99.22 & 4.22 \\
\hline 17 & & & & & & & & & 0.46 & 8 & 02 & & 96.38 & & 99.10 & \\
\hline 18 & & 8372.50 & 37.65 & 22.05 & 7.63 & 1.18 & 0.90 & 0.65 & 0.47 & .18 & 02 & & 96.31 & 96.37 & 99.09 & 4.99 \\
\hline 19 & & & & & & & & & & & & & & & 99.07 & \\
\hline 20 & 80 & 8791 & 37.49 & 21.48 & 7.37 & 1.12 & 0.89 & 0.64 & 0.45 & 8 & 02 & 0.02 & 96.22 & 96.29 & 99.05 & 5.06 \\
\hline 21 & $98-100$ & 9105.00 & 37.31 & 21.06 & 6.98 & 1.07 & 0.85 & 0.63 & 0.43 & 0.18 & 0.01 & 0.02 & 96.20 & 96.27 & 99.04 & 5.00 \\
\hline \multicolumn{3}{|c|}{ Average } & 37.07 & 17.92 & 7.05 & 1.07 & 0.71 & 0.57 & 0.49 & 0.38 & 0.04 & & 94.61 & 94.68 & 97.52 & 6.49 \\
\hline \multicolumn{3}{|c|}{ Minimum } & 31.35 & 13.31 & 5.09 & 0.93 & 0.56 & 0.51 & 0.37 & 0.15 & 0.01 & 0.01 & 91.56 & 91.65 & 94.87 & 4.22 \\
\hline \multicolumn{3}{|c|}{ Maximum } & 46.65 & 22.21 & 9.30 & 1.25 & 0.92 & 0.65 & 0.61 & 0.69 & 0.09 & 0.02 & 96.58 & 96.64 & 99.22 & 9.90 \\
\hline
\end{tabular}

Maximum bold minimum Italic 
Table 5. Trace elements content of the sediments from the Kukkal sediment core

\begin{tabular}{|c|c|c|c|c|c|c|c|c|c|c|c|c|c|c|c|c|}
\hline S.No & n) & Age & $\mathrm{Sr}$ & $\mathbf{Y}$ & $\mathrm{Zr}$ & $\mathbf{V}$ & $\mathrm{Cr}$ & $\mathrm{Ni}$ & $\mathrm{Cu}$ & Zn & $\mathbf{R b}$ & $\mathrm{Nb}$ & Pb & Th & $\mathbf{U}$ & Ba \\
\hline 1 & $2-4$ & 17.58 & 8.75 & 5.75 & 22.95 & 66.50 & 99.65 & 4.95 & 33.35 & 78.75 & 38.80 & 8.90 & 10.75 & 20.25 & 0.60 & 8.50 \\
\hline 2 & & & & & & & & & & & & & & & 65 & \\
\hline 3 & & & & & & 76.00 & & 4.50 & & & .80 & 70 & & & 30 & \\
\hline 4 & & & .80 & & & & & & & & & & & & 0 & \\
\hline 5 & & & & & & & & 7.10 & & & & 10.10 & & & 00 & \\
\hline 6 & & & 4.30 & .20 & 8.50 & 79.00 & 69.00 & 54.70 & 31.90 & 80.50 & 6.30 & 8.40 & 10 & 90 & 0.90 & \\
\hline 7 & & & & & & & & 9.60 & & & & & & & 80 & \\
\hline 8 & & & & & & & & & & & & 11.70 & & & 00 & \\
\hline 9 & & & .40 & .90 & & & 97.80 & 67.70 & 50.50 & 90.40 & 45.90 & 12.70 & & & 1.40 & \\
\hline 10 & & & & & & & 103.20 & 60.80 & & & & & & & 50 & \\
\hline 11 & & & 70 & & & & & 62.70 & & & 36.00 & & & & 1.60 & \\
\hline 12 & & & & & & & & & & & & & & & & \\
\hline 13 & & & 00 & 40 & & & & 68.90 & & 68.70 & 60 & 30 & 60 & 70 & 20 & \\
\hline 14 & & & 60 & & & & & 71.55 & & & 42.90 & & .40 & 33.80 & 1.60 & \\
\hline 15 & & & 47.20 & & 30 & 146 & 99.70 & 74.20 & & 75 & 20 & 13.20 & .20 & .90 & 00 & \\
\hline 16 & & & 51.10 & & 257.60 & 174.00 & 103.90 & 83.20 & & & 1.50 & & .70 & & 00 & \\
\hline 17 & & & 40 & & & & & 89.50 & & & 55.10 & & & & 20 & \\
\hline 18 & & 50 & 52.00 & 1.10 & 49.10 & 120.50 & 107.80 & 91.55 & 50.40 & 98.95 & 59.50 & 14.45 & 37.55 & 32.45 & 1.10 & 50 \\
\hline 19 & & & & & & & & & & & & & & & 1.00 & \\
\hline 20 & 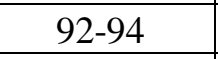 & 07 & 50.15 & 31.40 & 235.55 & 119.50 & 108.95 & 89.95 & 50.10 & 103.05 & 64.55 & 13.70 & 35.25 & 27.05 & 1.35 & .50 \\
\hline 21 & -100 & .00 & 48.70 & 32.40 & 207.50 & 91.00 & 107.40 & 86.30 & 49.40 & 101.40 & 65.20 & 12.80 & 31.60 & 24.20 & 1.70 & 320.00 \\
\hline \multicolumn{3}{|c|}{ Average } & 60.95 & 23.15 & 247.35 & & 88.72 & 69.54 & & 00.00 & $46 . / 8$ & 11.66 & 6.17 & 27.37 & .10 & 7.0 \\
\hline \multicolumn{3}{|c|}{ Minimum } & 47.20 & 14.90 & 207.50 & 57.00 & 61.40 & 54.50 & 31.90 & 68.70 & 36.00 & 8.40 & 7.30 & 19.40 & 0.30 & 267.00 \\
\hline \multicolumn{3}{|c|}{ Maximum } & 82.00 & 32.40 & 325.90 & 174.00 & 110.50 & 93.60 & 54.60 & 104.70 & 65.20 & 14.60 & 42.80 & 36.70 & 2.20 & 565.0 \\
\hline
\end{tabular}

Maximum bold, minimum bold italic. 
